\title{
OUTSOURCING TO NOT-FOR-PROFITS: CAN JUDICIAL ENFORCEMENT OF CHARITY LAW PROVIDE ACCOUNTABILITY FOR THE PERFORMANCE OF 'PUBLIC' FUNCTIONS?
}

\author{
IAN MURRAY* AND MURRAY WESSON**
}

\begin{abstract}
Governments increasingly rely on charities to provide services on behalf of government. Decisions on outsourced functions can relate to the distribution of public resources, such as the provision of housing, education or legal assistance. Accordingly, such decisions can be contentious and outsourcing potentially places that contention in the private sphere rather than the public sphere. This article examines the extent to which outsourcing service delivery to charities affects the ability of current or potential service recipients to hold decision-makers accountable. It argues that outsourcing government functions to charities will often place such functions beyond the scope of public law judicial review. However, charity law contains accountability mechanisms that have the potential to fill the gap. These mechanisms are identified and then compared with the availability of judicial review for government decisions by reference to scope, grounds, standing, time limits and remedies. This article finds that in many circumstances there should be no diminution of legal accountability. Nevertheless, charity law is less tested than administrative law, is not as effective in dealing with service decisions made by front line employees and does not as readily guarantee procedural fairness. Balanced against this, charity law may provide more generous time limits and better enable systemic issues to be addressed.
\end{abstract}

\section{INTRODUCTION}

In recent decades, Australian governments have increasingly turned to not-forprofits such as charities to deliver services that would previously have been

* Associate Professor, Law School, University of Western Australia.

** Senior Lecturer, Law School, University of Western Australia. The authors would like to thank Daniel McCluskey for research assistance in preparing this article and Professor Simon Young and Julie Falck for helpful comments. The authors would also like to thank the participants at a Charity Law Association of Australia and New Zealand conference and in a University of Western Australia Contemporary Government and Regulation seminar for their feedback, particularly that of the commentator, the Hon Robert French AC. Any errors remain the domain of the authors. 
provided directly by the state. To give a sense of the scale of the trend, total government funding to not-for-profits increased from $\$ 10.1$ billion in 1999/2000 to $\$ 40.9$ billion in 2012/13. ${ }^{1}$ This trend raises difficult questions at the juncture of public and private law. On the public law side, where a service is delivered by the state in terms of authorising legislation, there are multiple and well-established avenues that ensure the public law accountability of decision-makers to service recipients. These include merits review through tribunals such as the Administrative Appeals Tribunal; judicial review through the courts; the jurisdiction of Ombudsmen such as the Commonwealth Ombudsman; freedom of information legislation; ${ }^{2}$ and, in some states and territories, legislation that requires public authorities to act consistently with human rights. ${ }^{3}$ However, some of these mechanisms, such as merits review and judicial review, may fall away where a service is outsourced and delivered outside the terms of a statute. ${ }^{4}$ Outsourcing to charities may therefore result in a diminution of accountability for the performance of 'public' functions.

For example, in 1998 Australia's public employment service was replaced by a network of public, private and community bodies - now termed 'jobactive' which compete for contracts to provide services to unemployed people. Commentators have argued that the resulting fragmentation of decision-making between Centrelink officials exercising statutory powers and contracted service providers undermines the availability and effectiveness of merits review and judicial review. ${ }^{5} \mathrm{~A}$ job seeker who fails to attend an interview due to circumstances beyond their control, but nevertheless incurs a demerit due to the recommendation of a provider, may struggle to obtain a remedy. ${ }^{6}$

Likewise, the provision of social housing is increasingly outsourced to community housing organisations such as housing cooperatives and housing associations. ${ }^{7}$ Community housing organisations are subject to residential tenancy legislation that determines the private rights and duties of landlords and tenants and provides means of resolving disputes between them. However, the public law obligations of community housing organisations are less developed. ${ }^{8}$ In the recent

Productivity Commission (Cth), Contribution of the Not-for-Profit Sector (Research Report, 11 February 2010) 300; Australian Bureau of Statistics, Australian National Accounts: Non-Profit Institutions Satellite Account, 2012-13 (Catalogue No 5256.0, 28 August 2015).

2 See, eg, Freedom of Information Act 1982 (Cth) ss 4(1), 6C.

$3 \quad$ Human Rights Act 2004 (ACT) s 40B; Human Rights Act 2019 (Qld) s 5(2)(c); Charter of Human Rights and Responsibilities Act 2006 (Vic) s 6(2)(c).

4 Administrative Review Council, The Contracting out of Government Services (Report No 42, 25 August 1998) 81-91.

5 See, eg, Rachel Bacon, 'Rewriting the Social Contract: The SSAT, the AAT and the Contracting out of Employment Services’ (2002) 30(1) Federal Law Review 39.

6 Ibid 60.

7 Productivity Commission (Cth), Report on Government Services 2019 (Report, 22 January 2019) 18.2. See also Michael R Nancarrow, 'Community Housing Emerges from the Shadowlands: Property Rights and the Implications of a National Regulatory Framework under the Community Housing National Law' (2017) 42(1) Alternative Law Journal 35.

8 For a dated but insightful discussion, see Kathleen McEvoy and Chris Finn, 'The Public/Private Confluence: Administrative Law and Community Housing' (2010) 62 Australian Institute of Administrative Law Forum 30. 
case of Durney $v$ Unison Housing Ltd, ${ }^{9}$ for example, the Victorian Supreme Court found that decisions of a housing association to issue a notice to vacate and restrict contact by the plaintiff with its staff fell beyond the scope of judicial review and were not subject to administrative law principles.

To be sure, in some jurisdictions community housing organisations may be required to act compatibly with human rights legislation. ${ }^{10}$ There is also a National Regulatory System for Community Housing which provides for a 'National Law' to be implemented by the states and territories. ${ }^{11}$ The National Law stipulates that community housing providers should be 'fair, transparent and responsive' in their dealings with tenants and other clients. ${ }^{12}$ This formulation recognises the 'public' dimension of the work of community housing organisations to some extent while also falling short of the more extensive set of administrative law norms that apply where social housing is delivered directly by the state in terms of authorising legislation. The complaints mechanisms for the enforcement of these public law obligations of community housing organisations are also patchy and inconsistent. ${ }^{13}$ This may leave an applicant who has been denied social housing on the basis of information that the decision-maker has not shared with them, with limited grounds to challenge the decision. ${ }^{14}$

Similar issues may arise in other areas where charities make up a high share of providers, such as health and aged care, or the provision of education..$^{15}$ For instance, can the local community served by a private school challenge a decision to close the school? ${ }^{16}$ There is also an English example of a local charity school deciding, contrary to its governing rules, to mandate particular Anglican Church practices and to exclude non-Anglican students. ${ }^{17}$ The recent Religious Freedom Review demonstrates the potential for controversy over such issues in Australia for religious schools in receipt of public funding. ${ }^{18}$ While discrimination law is likely

9 (2019) 57 VR 158 ('Durney').

10 In Goode v Common Equity Housing Ltd [2016] VCAT 93 ('Goode'), the Victorian Civil and Administrative Tribunal found that a community housing organisation was subject to the Charter of Human Rights and Responsibilities Act 2006 (Vic) when providing social housing.

11 National Regulatory System for Community Housing, 'Regulatory Framework' (Framework, 27 July 2017) <https://www.nrsch.gov.au/_data/assets/file/0004/420871/NRSCH-Regulatory-FrameworkAmended-27-July-2017.pdf $>$.

12 Ibid 4.

13 Some jurisdictions have created independent and external processes for reviewing the decisions of community housing organisations but in much of Australia these are unavailable. The most robust systems are in New South Wales, where parties may appeal to the Housing Appeals Committee, and South Australia, where parties may appeal to the South Australian Civil and Administrative Tribunal. In Queensland, appeals may be made to the Housing and Appeals Review Unit. In Victoria, disgruntled parties are advised to complain to the Housing Registrar. Similarly, in Western Australia complaints may be made to the Community Housing Registration Office. In Tasmania, appeals should be made to the Community Partnership Team, then to the Director of Disability and Community Services, and finally to the Ombudsman. In the Australian Capital Territory and the Northern Territory, complaints should be made to the community housing organisation itself. McEvoy and Finn (n 8) 52 n 94.

15 Contribution of the Not-for-Profit Sector (n 1) xxxii.

16 Gunning v Buckfast Abbey Trustees Registered (1994) Times, 9 June 1994 ('Gunning').

17 A-Gv Governors of the Sherborne Grammar School (1854) 18 Beav 256; 52 ER 101 ('Sherborne').

Philip Ruddock et al, Religious Freedom Review (Report, 18 May 2018) 50-4. 
to be the primary battleground, charities (including religious bodies) are often subject to exceptions $;{ }^{19}$ and there is also the potential for discriminatory activities to affect charitable status. ${ }^{20}$

Given these difficulties, the article considers whether private law is capable of fostering accountability on the part of decision-makers to service recipients where 'public' functions have been outsourced to charities and merits review and judicial review are unavailable. However, the article does not consider all aspects of private law. There are already indications in the literature that contract law and tort law are subject to limitations. ${ }^{21}$ Our focus is upon charity law, since this area of law is underexplored in the context of outsourcing. The article also does not compare charity law to both merits review and judicial review. Charity law is not capable of substituting for merits review, given that charity law does not permit a court or tribunal to reconsider all aspects of the original decision and substitute its judgment for that of the decision-maker. The central issue explored in the article is whether judicial enforcement of charity law is capable of substituting for judicial review. It should be stressed that our argument is not that the scope of judicial review should be expanded to functions that have been outsourced to charities. Rather, our concern is whether charity law is capable of providing analogous forms of accountability to service recipients who have been adversely affected by charity decisions on outsourced functions..$^{22}$

Of course, it might be objected that disgruntled service recipients would be unlikely to turn to the courts, for either judicial review (where that is available) or judicial enforcement of charity law. However, even if judicial interventions are rare, there is value in clarifying the legal obligations applicable to charities delivering outsourced services given the potential to shape conduct throughout the sector. In other words, the mere knowledge that charity law obligations apply to

19 The Religious Freedom Review report notes that exceptions to the various discrimination laws currently permit (to varying degrees) discrimination in admitting students on the basis of religion: ibid 66-7. While the proposed religious freedom legislation released for public comment would prohibit discrimination in the admission of a student on the grounds of religious belief (clause 18), this is subject to potentially broad exceptions for religious bodies in clauses 10 and 11 and for registered charities in clause 28: Exposure Draft (29 August 2019), Religious Discrimination Bill 2019 (Cth). Some jurisdictions also provide limited rights to ministerial review of school decisions affecting individual students, but this is unlikely to apply to general policies: cf School Education Act 1999 (WA) s 233.

20 For a discussion of the role of public law equality norms under charity law, see especially Adam Parachin, 'Public Benefit, Discrimination and the Definition of Charity' in Kit Barker and Darryn Jensen (eds), Private Law: Key Encounters with Public Law (Cambridge University Press, 2013) 171.

21 The Contracting out of Government Services (n 4) 18-26; Carla Michler, 'Government by Contract: Who is Accountable?' (1999) 15 Queensland University of Technology Law Journal 135, 141-5; Rose Verspaandonk, 'Outsourcing: For and Against' (Current Issues Brief No 18, Parliamentary Library, Parliament of Australia, 26 June 2001) 11; Janina Boughey and Greg Weeks, “"Officers of the Commonwealth" in the Private Sector: Can the High Court Review Outsourced Exercises of Power' (2013) 36(1) University of New South Wales Law Journal 316, 324; Nicholas Seddon, Government Contracts: Federal, State and Local (Federation Press, $6^{\text {th }}$ ed, 2018) 49.

22 Accountability is not the only value promoted by judicial review. Other public law values include openness, fairness, participation, consistency, rationality, accessibility of judicial and non-judicial grievance procedures, legality and impartiality. See Mark Aronson, Matthew Groves and Greg Weeks, Judicial Review of Administrative Action and Government Liability (Thomson Reuters, $6^{\text {th }}$ ed, 2017) 4. However, in this article we generally employ 'accountability' as an umbrella term for these values. 
the delivery of outsourced functions may lead to better and more accountable service delivery. Indeed, knowledge of these obligations may also influence the extent to which other, 'easier', pathways are provided, such as merits review by a tribunal or access to an Ombudsman. To the extent that outsourced services have not been fully funded by government in the past, it may also remove an implicit rationale (of lower accountability) for such underfunding..$^{23}$

Our key finding is that there is potentially a significant overlap between the accountability achieved by judicial review and judicial enforcement of charity law. Grounds of review exist in charity law that are analogous to many of the grounds that apply in judicial review under the rubric of jurisdictional error or in terms of legislation such as the Administrative Decisions (Judicial Review) Act 1977 (Cth) ('ADJR Act'). ${ }^{24}$ The rules of standing in charity law are either similar to those that apply in judicial review or in some cases more open. Further, charity law remedies are potentially more far-reaching than those available in judicial review, given that they may better enable issues of systemic maladministration to be addressed. Admittedly, many of these charity law mechanisms are not supported by established bodies of authority and are underdeveloped. Nevertheless, outsourcing government functions to charities need not result in a diminution of legal accountability. Balanced against this, the article notes some concerns in relation to the scope of decisions to which charity law applies and in relation to 'procedural fairness' grounds. These are less available in the sphere of charity law than judicial review, yet may be significant for individuals aggrieved by service delivery failures.

These arguments are developed as follows. Part II clarifies the meaning of 'outsourcing', briefly explores why governments have turned to charities to deliver outsourced services and discusses the extent of the trend. Part III explores the scope of judicial review with respect to charity decisions on outsourced services and provides an overview of jurisdictional error and the grounds of judicial review, standing, time limits and remedies in judicial review. Part IV then analyses whether charity law rules of scope, grounds, standing, time limits and remedies are capable of substituting for those that exist in judicial review.

\section{THE PHENOMENON OF OUTSOURCING TO CHARITIES}

The term 'outsourcing' applies most obviously to funding a non-governmental entity to deliver services previously provided by the government. ${ }^{25}$ However, outsourcing can also refer to situations where the government decides to fund services previously delivered by non-governmental entities of their own accord, thereby assuming a degree of responsibility for the provision of the service. 'Outsourcing' as used in this article is therefore a broad concept, encompassing a range of practices that may be understood as 'the agency process of securing

23 As to underfunding, see, eg, Contribution of the Not-for-Profit Sector (n 1) 287.

24 Administrative Decisions (Judicial Review) Act 1977 (Cth) ('ADJR Act').

25 Cf the meaning of outsourcing as 'contracting out': Industry Commission, Competitive Tendering and Contracting by Public Sector Agencies (Research Report No 48, 24 January 1996) xix. 
another to provide goods or services directly to the public'. ${ }^{26}$ Outsourcing is distinct from 'privatisation' (which refers to government asset sales) ${ }^{27}$ and 'deregulation' (which means the lessening or removal of government intervention in the market place)..$^{28}$

The legal relationship between the government and non-government entities may take various forms. Historically, for example, Australian governments have frequently provided general purpose grants to charities. ${ }^{29}$ Here the government provides support but does not specify exact outcomes and allows the charity discretion in how best to use the funds. Accountability to the government is provided by the grant application process and subsequent acquittals..$^{30}$ Alternatively, the government may purchase specialised social services and specify the expected outcomes in contractual form. Accountability to the government is then provided by the contract and subsequent detailed performance reporting ${ }^{31}$ along with the government's ability to use general regulatory schemes and the promise of future funding to influence behaviour. In addition, the provision of some services, such as health or education services, is highly regulated such that legislative regimes require potential providers (and services) to be approved, thereby maintaining quality and grounding eligibility for payments. ${ }^{32}$ Functions may also be vested in charities by legislation. For example, most universities are created by their own statute, which provides for teaching, research and community service activities. ${ }^{33}$

The preceding paragraph hints at the diversity of charities. Charities can exist in a range of legal forms, with the majority of registered charities structured as incorporated associations or unincorporated associations and significant minorities comprising companies limited by guarantee and trusts. ${ }^{34}$ As the legal principles applying to unincorporated association charities are even less clear cut than those for incorporated charities or charitable trusts, we have focussed on the latter, although much of the discussion in this article would apply equally to

26 Mark Aronson, 'A Public Lawyer's Response to Privatisation and Outsourcing' in Michael Taggart (ed), The Province of Administrative Law (Hart Publishing, 1997) 40, 41.

27 Ibid.

28 Michael Taggart, 'The Nature and Functions of the State' in Peter Cane and Mark Tushnet (eds), The Oxford Handbook of Legal Studies (Oxford University Press, 2003) 101, 112.

29 John R Butcher, 'Not-for-Profits Must Adapt as One Arm of Government's "Three-Sector Solutions", The Conversation (online, 24 March 2017) <https://theconversation.com/not-for-profits-must-adapt-asone-arm-of-governments-three-sector-solutions-72971>.

30 Contribution of the Not-for-Profit Sector (n 1) 279.

31 Ibid. In the English and Canadian contexts, see also Kathryn Chan, The Public-Private Nature of Charity Law (Hart Publishing, 2016) 147-57; Don Bawtree and Kate Kirkland, Charity Administration Handbook (Bloomsbury Professional, $6^{\text {th }}$ ed, 2018) pt 5 ch 41.

32 As to such regulated areas, see, eg, Treasury (Cth), Scoping Study for a National Not-for-Profit Regulator (Final Report, April 2011) 22, 63.

33 Kwong Lee Dow and Valerie Braithwaite, Review of Higher Education Regulation (Report, Commonwealth of Australia, 2 August 2013) 20. Much ongoing funding is then received under a federal legislative regime.

34 Natasha Cortis et al, Australian Charities Report 2015 (Report, Centre for Social Impact and Social Policy Research Centre, University of New South Wales, December 2016) 49. 
unincorporated associations. To be charities such 'entities' ${ }^{35}$ must meet certain requirements. For the purposes of most federal legislation, those requirements are codified in the Charities Act 2013 (Cth). ${ }^{36}$ However, the common law meaning of charity remains applicable at the state and territory level to the creation of charitable trusts and some incorporated associations, as well as to state and local government tax concessions. ${ }^{37}$ The requirements are similar as the statutory definition is largely based upon and intended to preserve the pre-existing common law principles, but makes minor changes to modernise and clarify the meaning of 'charity'. ${ }^{38}$ Hence, recourse to the common law principles remains relevant. The requirements are that entities be not-for-profit, have purposes that are all 'charitable' purposes (such as relieving poverty, advancing education, advancing religion, or advancing other purposes beneficial to the community $)^{39}$ and be for the public benefit. ${ }^{40}$

In Australia, the last few decades have witnessed a marked increase in the degree to which non-governmental bodies, particularly charities, have been funded by all levels of government to provide human and community services, along with other functions. ${ }^{41}$ In 2017, government funding to charities registered with the Australian Charities and Not-for-Profits Commission ('ACNC'), Australia's federal charity regulator, amounted to $\$ 68$ billion $^{42}$ or $47 \%$ of total charity revenue. ${ }^{43}$ These developments are hardly unique to Australia. Throughout the Organisation for Economic Co-operation and Development, the rise of 'new public management' ${ }^{\prime 4}$ in the 1980 s and 1990 s resulted in increased reliance on market forces to address social problems and hence government support for private and

35 For brevity, 'entity' is used to include legal relationships, such as trusts and unincorporated associations, as well as legal persons.

36 Charities Act 2013 (Cth).

37 References to the 'common law' are to case law rather than legislation, unless the context requires otherwise.

38 Explanatory Memorandum, Charities Bill 2013 (Cth) and Charities (Consequential Amendments and Transitional Provisions) Bill 2013 (Cth) 3.

39 Under the Charities Act 2013 (Cth), charitable purposes have been reworded under 12 heads of charity that broadly reflect the scope of the general law heads. The reworded heads include, amongst others, advancing health, advancing education, advancing social or public welfare, advancing religion and advancing culture: at $\mathrm{s} 12(1)$.

40 Charities Act 2013 (Cth) ss 5, 6; Aid/Watch Inc v Federal Commissioner of Taxation (2010) 241 CLR 539, 548 [18] (French CJ, Gummow, Hayne, Crennan and Bell JJ) ('Aid/Watch Inc'). The entity must also not have any disqualifying purposes, such as purposes that are unlawful or contrary to public policy: Charities Act 2013 (Cth) s 11; Royal North Shore Hospital of Sydney v A-G (NSW) (1938) 60 CLR 396, 426 (Dixon J).

41 Contribution of the Not-for-Profit Sector (n 1) 300.

42 Australian Charities and Not-for-Profits Commission, Australian Charities Report 2017 (Report, May 2019) 22. Some charities, such as basic religious charities and independent schools, were not required to report such financial information to the Australian Charities and Not-for-Profits Commission ('ACNC').

43 Government grants include general purpose and purchase of service grants.

44 Contribution of the Not-for-Profit Sector (n 1) 303; Verspaandonk (n 21) 1-4; Myles McGregorLowndes, 'Is There Something Better than Partnership?' in Jo Barraket (ed), Strategic Issues for the Notfor-Profit Sector (University of New South Wales Press, 2008) 45, 46-9. 
voluntary actors ${ }^{45}$ However, Australia has been described as in the vanguard of these developments. ${ }^{46} \mathrm{An}$ inevitable result of these processes has been erosion of the boundaries between government, business and the not-for-profit sector. ${ }^{47}$

\section{THE LIMITS OF JUDICIAL REVIEW}

This 'scrambling' 48 of the public and private spheres may create difficulties for individuals who are adversely affected by decisions made by charities delivering outsourced services. The focus of this article is on the comparison between judicial review and judicial enforcement of charity law, and so this section first discusses the scope of judicial review. The picture that emerges is mixed but the overall conclusion is that judicial review is capable of providing only limited accountability to service recipients in respect of charity decisions on outsourced functions. In this section, we also briefly examine the grounds of review associated with the concept of jurisdictional error and applied under the ADJR Act, the rules of standing, time limits and remedies in judicial review. Much of this material will be familiar to readers knowledgeable about judicial review but it is necessary to facilitate the subsequent comparison with charity law and may also be helpful for readers approaching the article from a charity law background.

\section{A The Scope of Judicial Review}

Judicial review is a crucial mechanism for ensuring that decision-makers exercising public power - whether they are government ministers or civil servants at the lowest rungs of the state hierarchy ${ }^{49}$ - act within the ambit of their legal powers. However, in contexts such as outsourcing, difficult questions arise about whether a decision-maker is exercising public power and whether their decisions are amenable to judicial review. The scope of judicial review is not settled in Australian administrative law. A court will typically consider a range of factors,

45 Jennifer Brinkerhoff and Derek Brinkerhoff, 'Government-Nonprofit Relations in Comparative Perspective: Evolution, Themes and New Directions' (2002) 22(1) Public Administration and Development 3,5 .

46 Richard Shaw, 'New Public Management in Australia: Past, Present and Future' (2012) 141(2) Pouvoirs $117,117$.

47 As to the theoretical bases for the existence and extent of each of these sectors in relation to each other, see, eg, Richard Steinberg, 'Economic Theories of Nonprofit Organizations' in Walter Powell and Richard Steinberg (eds), The Nonprofit Sector: A Research Handbook (Yale University Press, $2^{\text {nd }}$ ed, 2006) 117. For a historical perspective on the relationships, see, eg, Paul Smyth, 'The Role of the Community Sector in Australian Welfare: A Brotherhood of St Laurence Perspective' in Jo Barraket (ed), Strategic Issues for the Not-for-Profit Sector (University of New South Wales Press, 2008) 212; Peter Dobkin Hall, 'A Historical Overview of Philanthropy, Voluntary Associations, and Nonprofit Organizations in the United States: 1600-2000' in Walter W Powell and Richard Steinberg (eds), The Nonprofit Sector: A Research Handbook (Yale University Press, $2^{\text {nd }}$ ed, 2006) 32, 57-8.

48 Peter Cane, 'Accountability and the Public/Private Distinction' in Nicholas Bamforth and Peter Leyland (eds), Public Law in a Multi-Layered Constitution (Hart Publishing, 2003) 247, 248.

49 The range of decisions to which judicial review potentially applies is emphasised as a point of contrast to charity law. However, it should be noted that decisions of the Governor-General are not subject to judicial review under the ADJR Act 1977 (Cth) s 3(1)(c). Vice-regal decisions are amenable to judicial review under the common law: $R v$ Toohey; Ex parte Northern Land Council (1981) 151 CLR 170. 
including the source of power, the nature of the decision and whether it is justiciable, and the identity of the decision-maker. A complication is that these factors may assume different legal significance in different judicial review jurisdictions.

The discussion in this section is organised around the multiple sources of judicial review jurisdiction that exist at federal, state and territory levels. The High Court has 'original jurisdiction' under section 75(v) of the Commonwealth Constitution, where 'a writ of Mandamus or prohibition or an injunction is sought against an officer of the Commonwealth'. The High Court also has original jurisdiction under section 75(iii) of the Constitution, in all matters 'in which the Commonwealth, or a person suing or being sued on behalf of the Commonwealth, is a party'. The relationship between these provisions is unclear, although it has been suggested that they overlap '[a]t least to a large extent'. ${ }^{50}$ Section 39B of the Judiciary Act 1903 (Cth) confers a judicial review jurisdiction on the Federal Court that is almost identical to the High Court's jurisdiction under section 75(v) of the Constitution. ${ }^{51}$ The Federal Court and the Federal Circuit Court also have judicial review jurisdiction under section 8 of the ADJR Act. The state and territory Supreme Courts possess an inherent supervisory jurisdiction derived from the superior courts of England. Further, in Kirk v Industrial Court (NSW) ('Kirk') $)^{52}$ the High Court found that this common law jurisdiction is also constitutionally entrenched, at least to the extent that the Supreme Courts retain the power to grant relief for jurisdictional error. ${ }^{53}$ In addition, in some states and territories, courts have statutory sources of judicial review jurisdiction. ${ }^{54}$

Starting with the original jurisdiction of the High Court and the corresponding jurisdiction of the Federal Court, the scope of judicial review is limited by the requirement that a remedy must be sought against an 'officer of the Commonwealth'. For our purposes, the issue that arises is whether charity directors, trustees or employees are 'officers of the Commonwealth' when they are performing an outsourced function.

In $R v$ Murray; Ex parte Commonwealth, ${ }^{55}$ Isaacs $\mathrm{J}$ held that a 'direct connection' is required between the Commonwealth and the person against whom an order is sought: 'the person referred to [must be] individually appointed by the

50 Deputy Commissioner of Taxation v Richard Walter Pty Ltd (1995) 183 CLR 168, 204 (Deane and Gaudron JJ). See also Aronson, Groves and Weeks (n 22) 56-8.

51 Section 39B(1) provides 'the original jurisdiction of the Federal Court of Australia includes jurisdiction with respect to any matter in which a writ of mandamus or prohibition or an injunction is sought against an officer or officers of the Commonwealth'.

52 (2010) 239 CLR 531, 580-1 [96]-[100] (French CJ, Gummow, Hayne, Crennan, Kiefel and Bell JJ) ('Kirk').

53 The entrenched judicial review jurisdiction of the Supreme Courts may be limited to the prerogative writs and not the equitable remedies. See the recent decision of the New South Wales Supreme Court in Kaldas v Barbour (2017) 326 FLR 122 ('Kaldas'). 
Commonwealth ...' ${ }^{56}$ However, as Groves notes, outsourcing raises a difficult question for Isaacs J's test: ${ }^{57}$

Should people employed in the private sector and who perform tasks that are ultimately designed to benefit the Commonwealth be regarded as officers of the Commonwealth for the purposes of $\mathrm{s} 75(\mathrm{v})$ to the extent that their work affects or involves functions that might otherwise be performed by federal officials?

This problem was considered in Plaintiff M61/2010E v Commonwealth ('Plaintiff M61'), ${ }^{58}$ where an independent merits review of asylum claims was conducted by employees from a private company engaged by the Department of Immigration and Citizenship for this task. The High Court unanimously found that it was $^{59}$

appropriate to leave, for another day, the question of whether a party identified as 'an independent contractor' nevertheless may fall within the expression 'an officer of the Commonwealth' in s $75(\mathrm{v})$ in circumstances where some aspect of the statutory or executive authority of the Commonwealth has been 'contracted out'.

As it stands, it follows that there is limited scope under the High Court's original jurisdiction and the corresponding jurisdiction of the Federal Court to review charity decisions on outsourced services, at least where the service is delivered in terms of a grant or contract. ${ }^{60}$ The situation may be different where a decision-maker is exercising statutory powers formally delegated to them under a statute. In these circumstances, there may be a sufficient nexus between the Commonwealth and the decision-maker for the latter to be regarded as an 'officer of the Commonwealth'. ${ }^{61}$ That was not the case in Plaintiff M61, where the statutory powers were not delegated and could only be exercised by the minister personally.

Turning to the ADJR Act, the scope of judicial review is restricted by the requirement that there must be a 'decision of an administrative character made ... under an enactment' ${ }^{62}$ Each of the elements of this formulation has generated significant case law. However, the requirement that a reviewable decision must be made 'under an enactment' is especially significant in the outsourcing context. For example, in NEAT Domestic Trading Pty Ltd v AWB Ltd ('NEAT'), ${ }^{63}$ the Wheat Marketing Act 1989 (Cth) provided that only AWBI Ltd (a private corporation) had the legal power to export wheat. The Act allowed the Wheat Export Authority (a government statutory corporation) to issue consent for others to export wheat. However, in terms of the Act, the Wheat Export Authority could not do so unless it had received AWBI's 'prior approval in writing'. ${ }^{64} \mathrm{McHugh}$, Hayne and Callinan $\mathrm{JJ}$ held that AWBI derived its power to issue prior approval not from the Act but

56 Ibid 453.

57 See Matthew Groves, 'Outsourcing and s 75(v) of the Constitution' (2011) 22(1) Public Law Review 3, 5 ('Outsourcing').

58 (2010) 243 CLR 319 ('Plaintiff M61').

59 Ibid 345 [51] (French CJ, Gummow, Hayne, Heydon, Crennan, Kiefel and Bell JJ).

60 For academic criticism, see Groves, 'Outsourcing' (n 57); Boughey and Weeks (n 21) 324.

61 Carter v Minister for Aboriginal Affairs (2005) 143 FCR 383, 393 [31] (Ryan J).

62 ADJR Act 1977 (Cth) s 3(1) (definition of 'decision to which this Act applies' para (a)).

63 (2003) 216 CLR 277 ('NEAT'). For critique, see Mark Aronson, 'Private Bodies, Public Power and Soft Law in the High Court' (2007) 35(1) Federal Law Review 1. 
its status as a company. For this reason, AWBI's decisions in this regard were not made 'under an enactment' ${ }^{65}$ for the purposes of the ADJR Act. The majority also doubted the applicability of public law norms to AWBI, ${ }^{66}$ a private corporation entitled to behave in a profit-maximising manner. The majority in NEAT did not consider the Datafin principle, but the outcome contrasts with the approach developed by the English courts where the focus is on the nature of the function exercised by the body. ${ }^{67}$ Of course, a charity delivering an outsourced service is not wholly analogous to a private company focused upon the pursuit of its commercial interests. Charities, although privately created, pursue purposes that benefit the public. However, given that charities typically perform outsourced functions in terms of a grant or contract, as opposed to a statute, NEAT casts doubt on the reviewability of their decision-making under the ADJR Act.

The meaning of 'under an enactment' was also considered by the High Court in Griffith University v Tang ('Tang'). ${ }^{68}$ A doctoral student challenged her exclusion from her PhD program for allegedly fabricating research results. The student brought her application under the Judicial Review Act 1991 (Qld), which like the ADJR Act stipulates that a reviewable decision must be made 'under an enactment' ${ }^{69}$ Gummow, Callinan and Heydon JJ held that whether this provision is satisfied depends upon two criteria: "first, the decision must be expressly or impliedly required or authorised by the enactment; and, secondly, the decision must itself confer, alter or otherwise affect legal rights or obligations, and in that sense must derive from the enactment'. ${ }^{70}$ The plurality accepted that the decision was authorised by the Griffith University Act 1998 (Qld) but found against the applicant because the manner in which she had framed her application for judicial review meant that she failed to establish that the decision affected her legal rights and obligations. ${ }^{71}$

The result of Tang is that a reviewable decision for the purposes of the ADJR $A c t$ must not only be authorised by a statutory provision and affect legal rights and obligations, but affect legal rights and obligations by virtue of the statutory provision..$^{72}$ Thus a decision to exercise contractual power, made under legislation that confers the capacity to exercise such power, would not be reviewable under the ADJR Act if it derived its legal effect not from the statute but the ordinary law of contract. In the earlier case of Australian National University v Burns,${ }^{73}$ for instance, the Federal Court found that a decision to terminate an employment contract was not made 'under an enactment' given that the source of power was the law of contract and not the statute that enabled the contract to be made in the first place. Clearly, the combined effect of NEAT and Tang is to preclude review

65 Ibid 298.

66 Ibid 298-300.

$67 R$ v Panel on Take-overs and Mergers; Ex parte Datafin plc [1987] QB 815 ('Datafin'). Datafin was considered by Kirby J in dissent: see NEAT (2003) 216 CLR 277, 313-14 [112]-[115].

68 (2005) 221 CLR 99 ('Tang').

69 Section 4(a).

70 Tang (2005) 221 CLR 99, 130 [89].

71 Ibid 131 [91] (Gummow, Callinan and Heydon JJ).

72 Seddon (n 21) 439.

73 (1982) 43 ALR 25. See also General Newspapers Pty Ltd v Telstra (1993) 45 FCR 164. 
under the ADJR Act where a charity performs an outsourced function in terms of a grant or contract. However, review may also be unavailable where a function is vested in a charity by legislation, at least where the decision derives its legal effect from the general law as opposed to the statute. For Seddon, the case law in this area has 'hobbled the ability of courts to review decisions that are clearly in the public domain'. ${ }^{74}$

The picture is less straightforward at state and territory level. Where state and territory legislatures have invested their Supreme Courts with powers of judicial review, the scope of judicial review under these Acts is often defined in terms similar to the ADJR Act. The Judicial Review Act 2000 (Tas) and the Administrative Decisions (Judicial Review) Act 1977 (ACT) both refer to decisions made 'under an enactment' ${ }^{75}$ The Judicial Review Act 1991 (Q1d) adopts the same formulation ${ }^{76}$ while also allowing for judicial review of decisions made under nonstatutory schemes in a limited range of circumstances. ${ }^{77}$ Victoria's Administrative Law Act 1978 adopts a different formulation by limiting the scope of judicial review to 'decision[s]' of 'tribunal[s]'. ${ }^{78}$ In terms of section 2 of this Act, a 'decision' is defined in terms of rights, privileges and licences, while a 'tribunal' means parties required by law to adhere to the rules of natural justice. In practice, the scope of statutory judicial review in Victoria has been restricted to the supervision of 'public power' in a manner that broadly accords with the common law. ${ }^{79}$

The state and territory Supreme Courts also possess an inherent supervisory jurisdiction sourced in the common law, aspects of which the High Court recognised as constitutionally entrenched in Kirk. ${ }^{80}$ The constitutionally entrenched judicial review jurisdiction of the Supreme Courts is similar to the jurisdiction conferred by section $75(\mathrm{v})$ of the Constitution although it is not limited by the 'officer of the Commonwealth' requirement. ${ }^{81}$ This may generate a greater willingness to review the decisions of charity officers performing outsourced functions. In addition, in the exercise of their inherent jurisdiction, at least some

74 Seddon (n 21) 441. See, eg, King v Director of Housing (2013) 23 Tas R 353.

75 Administrative Decisions (Judicial Review) Act 1989 (ACT) s 3(1); Judicial Review Act 2000 (Tas) s 4(1).

76 Judicial Review Act 1991 (Qld) s 4(a).

77 The Judicial Review Act 1991 (Qld) s 4(b) provides that the Act applies to decisions of 'an administrative character made, or proposed to be made, by, or by an officer or employee of, the State or a State authority or local government authority under a non-statutory scheme or program involving funds that are provided or obtained (in whole or part)- (i) out of amounts appropriated by Parliament; or (ii) from a tax, charge, fee or levy authorised by or under an enactment'. This provision has limited relevance to decisions made by charities performing outsourced functions. See Justice Catherine Holmes, 'Not Making a Difference: Queensland's Extension of Statutory Review' (2016) 85 Australian Institute of Administrative Law Forum 1; Aronson, Groves and Weeks (n 22) 32-3.

78 Administrative Law Act 1978 (Vic) s 2.

79 Aronson, Groves and Weeks (n 22) 36-7. For example, in Borg v Smith [1991] 2 VR 161 it was held that the trustees of a superannuation fund were not subject to judicial review even though the fund was authorised by the statutory corporation's enabling Act.

80 Kirk (2010) 239 CLR 531.

81 A further point of distinction may be that the entrenched judicial review jurisdiction of the Supreme Courts may be limited to the prerogative writs and not the equitable remedies: Kaldas (2017) 326 FLR 122 . 
state and territory courts have demonstrated a greater receptiveness to the Datafin principle, although it remains unclear whether Datafin forms part of the Australian common law. ${ }^{82}$ Further, although the prerogative remedies of certiorari and prohibition have historically only applied to public or statutory bodies, ${ }^{83}$ this is not the case for the remedies of declaration and injunction which have their origins in private law. ${ }^{84}$ State and territory Supreme Courts have sometimes been willing to issue declarations and injunctions regarding decisions of 'private' bodies tainted by errors that would have constituted jurisdictional error had they been made by 'public' bodies. ${ }^{85}$ Of the various jurisdictions surveyed, the supervisory jurisdiction of the state and territory Supreme Courts may be the most promising for parties seeking judicial review of charity decisions on outsourced functions.

Nevertheless, the case law has not been clearly developed. ${ }^{86}$ Applicants proceeding under the common law would also be limited to the equitable remedies and would not have access to the prerogative writs. Given the uncertainty surrounding the public/private divide in the common law, and the remedial limitations that apply, it is worth exploring alternative avenues of accountability that exist in charity law. This approach also has the advantage of not requiring a court to expressly confront the public/private law distinction when asked to review a decision of a charity exercising an outsourced function. Turning to charity law to provide accountability to service recipients in the context of outsourced services may allow both courts and litigants to evade vexed threshold questions in judicial review and focus on the substantive issues.

Finally, an additional source of accountability in respect of charity decisions on outsourced functions is available under the jurisdiction of the Federal Court. Section 39B(1A)(c) of the Judiciary Act 1903 (Cth) provides the Federal Court with original jurisdiction in any matter 'arising under any laws made by the Parliament'. For jurisdiction to exist there must be a 'matter' that 'arises under' federal law. The latter requirement has been interpreted broadly to include situations where federal law establishes a right that one of the parties is seeking to vindicate $^{87}$ or a defence upon which one of the parties is seeking to rely. ${ }^{88} \mathrm{In}$

82 There are conflicting decisions at state and territory level and an absence of clear guidance from the High Court. Datafin has, for example, been applied by the Victorian Supreme Court (pre-NEAT) in State of Victoria v Master Builders' Association of Victoria [1995] 2 VR 121 and the New South Wales Supreme Court in Masu Financial Management Pty Ltd v Financial Industry Complaints Service Ltd [No 2] (2004) 50 ACSR 554. However, in the New South Wales Court of Appeal, Basten JA cast doubt upon the applicability of Datafin in Australia in Chase Oyster Bar Pty Ltd v Hamo Industries Pty Ltd (2010) 78 NSWLR 393. See Justice Emilios Kyrou, 'Judicial Review of Decisions of Non-Governmental Bodies Exercising Governmental Powers: Is Datafin Part of Australian Law?' (2012) 86(1) Australian Law Journal 20.

83 R v Criminal Injuries Compensation Board; Ex parte Lain [1967] 2 QB 864.

84 See, eg, Forbes $v$ New South Wales Trotting Club Ltd (1979) 143 CLR 242 where declaratory relief was sought against a non-government body exercising a 'public' function.

85 See, eg, McClelland v Burning Palms Surf Life Saving Club (2002) 191 ALR 759.

86 Colin Campbell, 'The Public/Private Distinction in Australian Administrative Law' in Matthew Groves and HP Lee (eds), Australian Administrative Law: Fundamentals, Principles and Doctrines (Cambridge University Press, 2007) 34.

87 See, eg, Australian Solar Mesh Sales Pty Ltd v Anderson (2000) 101 FCR 1, 7-8 (Burchett J).

88 See, eg, Moorgate Tobacco v Phillip Morris (1980) 145 CLR 457, 476 (Stephen, Mason, Aickin and Wilson JJ) ('Moorgate'). For a useful discussion of these issues, see Justice James Allsop, 'An 
addition, if a right or duty under a federal law must be determined as part of a broader process of vindicating or defending a position, then jurisdiction will exist. ${ }^{89} \mathrm{~A}$ dispute about compliance with the governance standards that apply to charities under the Australian Charities and Not-for-Profits Commission Act 2012 (Cth) ('ACNC Act' $)^{90}$ might therefore fall within the jurisdiction of the Federal Court in some circumstances. However, compliance with the governance standards gives charities a right to be registered and hence to qualify for tax and other concessions. ${ }^{91}$ Non-compliance enables the ACNC, but not the recipients of charity benefits, to take certain enforcement actions, including deregistration. For disgruntled service recipients then, this avenue may only apply in limited circumstances..$^{92}$ For instance, it might sometimes be possible to establish that causing a charity to breach the governance standards is a step in the process of demonstrating breach of duties such as the duty of care, skill and diligence on the part of charity controllers. ${ }^{93}$

\section{B Jurisdictional Error and 'Grounds' of Judicial Review}

Historically, judicial review developed through the provision of certain remedies, especially the prerogative writs. The applicant had to persuade the court that the criteria for the award of the remedy were satisfied. The ADJR Act shifted the emphasis from the availability of particular remedies to whether one or more of the 'grounds of review' listed in section 5 of the Act was established. However, in Australia, doubt has now been cast upon the continuing utility of conceptualising judicial review primarily in terms of grounds of review. Bateman and McDonald, for example, contrast the 'grounds approach', which involves the application of rules and principles that exist ex ante a statute conferring power on an administrator, with the 'statutory approach', whereby the constraints on administrative discretion are determined through a process of statutory interpretation undertaken ex post the enactment of the statute conferring administrative power. ${ }^{94}$ The authors contend that since the 1990s there has been a fundamental shift in Australian administrative law to the statutory approach. The result is less emphasis on the judicial articulation of grounds of review that exist prior to the enactment of a statutory power, in favour of an approach that 'rivets the analysis to the particulars of statutory purposes'. ${ }^{95}$

Introduction to the Jurisdiction of the Federal Court of Australia' (Speech, Federal Court of Australia, 1 October 2007) 15.

89 See, eg, Moorgate (1980)145 CLR 457, 476 (Stephen, Mason, Aickin and Wilson JJ); Allsop (n 88).

90 Australian Charities and Not-for-Profits Commission Act 2012 (Cth) ('ACNC Act').

91 See below nn 188-95 and accompanying text.

92 Of course, section 39B(1) of the Judiciary Act 1903 (Cth) should apply to decisions about enforcement action under the ACNC Act made by the ACNC Commissioner and his delegates, as 'officers of the Commonwealth'.

93 Cf Australian Solar Mesh Sales Pty Ltd v Anderson (2000) 101 FCR 1.

94 Will Bateman and Leighton McDonald, 'The Normative Structure of Australian Administrative Law' (2017) 45(2) Federal Law Review 153. See also Justice John Basten, 'Judicial Review: Can we Abandon Grounds?' (2018) 93 Australian Institute of Administrative Law Forum 22. 
Integral to this development has been the emergence of jurisdictional error as the 'meta-principle' of judicial review. ${ }^{96}$ Jurisdictional error is established if 'the decision maker makes a decision outside the limits of the functions and powers conferred on him or her, or does something which he or she lacks power to do'. ${ }^{97}$ This contrasts with errors within jurisdiction, which involve incorrectly deciding something which the decision-maker is authorised to decide. Under the High Court's original jurisdiction in section 75(v) of the Constitution, the constitutional writs of mandamus and prohibition are available only for jurisdictional error. In the supervisory jurisdiction of the state and territory Supreme Courts, the prerogative writs, with the exception of certiorari, ${ }^{88}$ are likewise available only for jurisdictional error. Jurisdictional error also defines the constitutionally entrenched judicial review jurisdiction of the High Court ${ }^{99}$ and state Supreme Courts. ${ }^{100}$ In keeping with the 'statutory approach' identified by Bateman and McDonald, the High Court has emphasised that whether a given error is jurisdictional 'depends upon the construction of the Act to determine whether it was a purpose of the Act that an act done or not done, in breach of the provision, should be invalid'. ${ }^{101}$ Recent case law also suggests that the error should be 'material' in the sense that compliance with the statutory condition could realistically have resulted in a different outcome. ${ }^{102}$ In Kirk, the High Court cautioned that the 'metes and bounds' ${ }^{103}$ of jurisdictional error cannot be clearly defined. The grounds of review are merely examples of jurisdictional error as opposed to a 'rigid taxonomy'.104 Indeed, there is no 'comprehensive, universally-accepted list of grounds of review'. ${ }^{105}$

Nevertheless, it is difficult to abandon the terminology of grounds of review entirely. First, the 'grounds approach' remains central to the ADJR Act and much of the judicial review legislation enacted in the states and territories. Second, as Bateman and McDonald note, 'even where the full force of the statutory approach is evident, the language of the grounds of review can be found'. ${ }^{106}$ Grounds of

96 Aronson, Groves and Weeks (n 22) 41.

97 Re Refugee Review Tribunal; Ex parte Aala (2000) 204 CLR 82, 141 [163] (Hayne J) ('Aala') quoted in Kirk (2010) 239 CLR 531, 571 [66] (French CJ, Gummow, Hayne, Crennan, Kiefel and Bell JJ).

98 Certiorari is also available for non-jurisdictional error of law on the face of the record. See Aronson, Groves and Weeks (n 22) 847.

99 Plaintiff S157/2002 v Commonwealth (2003) 211 CLR 476, 513 [103] (Gaudron, McHugh, Gummow, Kirby and Hayne JJ).

100 Kirk (2010) 239 CLR 531, 581 [99]-[100] (French CJ, Gummow, Hayne, Crennan, Kiefel and Bell JJ).

101 Re Minister for Immigration and Multicultural and Indigenous Affairs; Ex parte Palme (2003) 216 CLR 212, 224 [44] (Gleeson CJ, Gummow and Heydon JJ).

102 Hossain v Minister for Immigration and Border Protection (2018) 264 CLR 123, 134-5 [29]-[31] (Kiefel CJ, Gageler and Keane JJ), 145-8 [66]-[72] (Edelman J) ('Hossain'); Minister for Immigration and Border Protection v SZMTA (2019) 264 CLR 421, 445-6 [45]-[51] (Bell, Gageler and Keane JJ) ('SZMTA'). The High Court is not unanimous on whether materiality is required for jurisdictional error. Nettle J dissented in Hossain (2018) 264 CLR 123 on this point at 136-9 [39]-[43] and Nettle and Gordon JJ dissented in SZMTA (2019) 264 CLR 421 at 455-60 [81]-[95].

103 Kirk (2010) 239 CLR 531, 573 [71] (French CJ, Gummow, Hayne, Crennan, Kiefel and Bell JJ).

104 Ibid 574 [73] (French CJ, Gummow, Hayne, Crennan, Kiefel and Bell JJ).

105 Judith Bannister, Anna Olijnyk and Stephen McDonald, Government Accountability: Australian Administrative Law (Cambridge University Press, $2^{\text {nd }}$ ed, 2018) 374. 
review continue to figure as non-exhaustive and overlapping examples of jurisdictional error. Although coloured by the statutory context of the particular case, they 'represent principles that apply generally to administrative powers across a number of different contexts' ${ }^{107}$

For these reasons, although mindful of the caveats set out above, in this section we briefly set out some of the key grounds of review found at common law and in judicial review legislation. As we shall see in the sections that follow, this is necessary to facilitate the comparison with charity law.

First, there are grounds addressing 'procedural fairness'. ${ }^{108}$ Procedural grounds of review include the rules of natural justice ie, the fair hearing rule and the rule against bias. In Kioa $v$ West, Mason $\mathbf{J}$ held that there is a common law duty to provide a fair hearing where an administrative decision affects a person's rights, interests or legitimate expectations. ${ }^{109}$ In subsequent cases, the High Court has moved away from the language of legitimate expectations, finding that it 'either adds nothing or poses more questions than it answers and thus is an unfortunate expression which should be disregarded'. ${ }^{110}$ The focus is instead upon what fairness requires in the particular case. ${ }^{111}$ In addition to procedural grounds of review stemming from natural justice, there are statutory rules of procedure.

Second, there are grounds that structure the 'reasoning processes' of decisionmakers in the exercise of their administrative discretion. ${ }^{12}$ Decision-makers may not, for example, take an irrelevant consideration into account or fail to take account of a relevant consideration; fetter their discretion; act under dictation; or exercise a power for an improper purpose or in bad faith. ${ }^{113}$ Administrative decisions may also be reviewed for unreasonableness. In the landmark Associated Picture Houses Ltd v Wednesbury Corporation ('Wednesbury') case, the English Court of Appeal found that this ground applies to a decision that is so unreasonable that no reasonable decision-maker could have reached it. ${ }^{114}$ In Australia, a High Court plurality qualified this standard in Minister for Immigration and Citizenship $v L i$, finding that the 'legal standard of unreasonableness should not be considered as limited to what is in effect an irrational, if not bizarre, decision'. ${ }^{115}$ The threshold of unreasonableness is instead 'indicated by the true construction of the statute'. ${ }^{116}$ These propositions were confirmed in Minister for Immigration and Border Protection v SZVFW, ${ }^{117}$ although the High Court also took care to emphasise that

107 Aronson, Groves and Weeks (n 22) 22.

108 Ibid chs 7-9.

109 (1985) 159 CLR 550, 585.

110 Plaintiff S10/2011 v Minister for Immigration and Citizenship (2012) 246 CLR 636, 658 [65] (Gummow, Hayne, Crennan and Bell JJ).

111 Minister for Immigration and Border Protection v WZARH (2015) 256 CLR 326, 343 [61] (Gageler and Gordon JJ).

112 Aronson, Groves and Weeks (n 22) 280; Peter Cane, Leighton McDonald and Kristen Rundle, Principles of Administrative Law (Oxford University Press, $\left.3^{\text {rd }} \mathrm{ed}, 2018\right) 162$.

113 Aronson, Groves and Weeks (n 22) 279-94, 300-34.

114 Associated Picture Houses Ltd v Wednesbury Corporation [1948] 1 KB 223, 229-30 (Lord Greene MR). This formulation is reflected in the ADJR Act 1977 (Cth) ss 5(2)(g), 6(2)(g).

115 (2013) 249 CLR 332, 364 [68] (Hayne, Kiefel and Bell JJ).

116 Ibid 364 [67].

117 (2018) 264 CLR 541. 
a court cannot simply substitute its view of what is reasonable for that of the decision-maker and so a finding of unreasonableness will not be lightly reached. ${ }^{118}$

Third, there are grounds of review that are not easily accommodated in the distinction between procedural fairness and the decision-maker's 'reasoning process' and which we refer to as the 'third category' of grounds of review. A decision-maker may not delegate their powers to another party, ${ }^{119}$ or act without legal authorisation. ${ }^{120}$ Errors of fact may be reviewed in limited circumstances: these should be 'jurisdictional facts' or relate to the 'no evidence' ground of review at common law or under the ADJR Act. ${ }^{121}$ Errors of law are reviewable under the $A D J R$ Act although the error must be "material to the decision in the sense that it contributes to it so that, but for the error, the decision would have been, or might have been, different'. ${ }^{122}$ The position is more complex at common law: judicial review is confined to errors of law which are jurisdictional and meet the threshold of materiality, although this constraint does not apply to declarations and injunctions and certiorari is available for non-jurisdictional errors of law on the face of the record. ${ }^{123}$

\section{Standing}

Even if a decision falls within the scope of judicial review and appears to involve jurisdictional error, or breach a ground of review under the ADJR Act, the applicant must have standing. In Australian Conservation Foundation $v$ Commonwealth, a case involving an application for declaratory relief at common law, Gibbs J held that to establish standing the applicant must demonstrate a 'special interest' that distinguishes them from others. ${ }^{124}$ Importantly, a special interest should entail more than a 'mere intellectual or emotional concern'. ${ }^{125}$ In other words, a belief, however strongly felt, that a particular law should be enforced by the court, is insufficient to establish standing. ${ }^{126}$

This approach presents difficulties for environmental and other public interest groups, since their beliefs are typically widely held and strongly felt. ${ }^{127}$ However, the special interest test allows for flexible application. In Bateman's Bay Local Aboriginal Land Council v Aboriginal Community Fund Pty Ltd ('Bateman's Bay'), for example, Gaudron, Gummow and Kirby JJ held that what constitutes a 'special interest' depends upon the 'nature and subject matter of the litigation' 128 and the requirement should be 'construed as an enabling, not a restrictive,

118 Ibid 551 [11] (Kiefel CJ), 564 [52] (Gageler J), 574 [84] (Nettle and Gordon JJ), 586 [135] (Edelman J).

119 Aronson, Groves and Weeks (n 22) 336-49.

120 Ibid 360-2.

121 Ibid 244-77.

122 Australian Broadcasting Tribunal v Bond (1990) 170 CLR 321, 353 (Mason CJ).

123 Aronson, Groves and Weeks (n 22) 223.

124 Australian Conservation Foundation v Commonwealth (1980) 146 CLR 493, 530.

125 Ibid.

126 Ibid.

127 Matthew Groves, 'The Evolution and Reform of Standing in Australian Administrative Law' (2016) 44(2) Federal Law Review 167, 172 ('The Evolution and Reform of Standing').

128 (1998) 194 CLR 247, 262-6 [46] ('Bateman's Bay'). 
procedural stipulation'. ${ }^{29}$ There are indications of a more 'subtle and liberal' approach in the lower courts, especially in environmental litigation. ${ }^{130}$ In North Coast Environmental Council Inc v Minister for Resources, ${ }^{131}$ for instance, a multifactorial approach was adopted in determining that an environmental group had standing. The High Court has also indicated that there may be looser rules of standing for the common law remedies of prohibition and certiorari, ${ }^{132}$ although commentators have noted that in practice the common law tests of standing appear to be converging. ${ }^{133}$ The case law under the $A D J R A c t$, which requires that an applicant be a person 'aggrieved by a decision' ${ }^{134}$ is broadly synonymous with the High Court's special interest test. ${ }^{135}$

In contrast, the Attorney-General always has standing to bring judicial review proceedings. Further, a person who lacks standing to apply for judicial review in their own name may be given permission to do so in the Attorney-General's name by way of a 'relator action'. However, in practice this procedure is rarely used. As Gaudron, Gummow and Kirby JJ remark in Bateman's Bay, it may be 'somewhat visionary' for citizens to suppose that they may rely upon the grant of the AttorneyGeneral's fiat 'for protection against ultra vires action of statutory bodies for the administration of which a ministerial colleague is responsible'. ${ }^{136}$ Of course, this concern is less pressing in the context of outsourcing, where services are usually delivered outside the terms of statutes and ministers are to some extent divested of responsibility. Nevertheless, relevant case law is difficult to identify, which is perhaps unsurprising given that, as we have seen, judicial review does not typically extend to decisions on outsourced services.

\section{Time Limits}

Judicial review applications are also subject to time limits. Under the $A D J R$ $A c t$, an application for judicial review must be made within 28 days of a Commonwealth decision. ${ }^{137}$ There are similar time limits under state and territory judicial review legislation. ${ }^{138}$ The time limits for the prerogative orders (mandamus, prohibition and certiorari) are more flexible. These range from extendable three-month limits in New South Wales ${ }^{139}$ and Queensland ${ }^{140}$ to an

129 Ibid 267 [50].

130 Groves, 'The Evolution and Reform of Standing' (n 127) 198.

131 (1994) 55 FCR 492, 512-13 (Sackville J).

132 Aala (2000) 204 CLR 82, 124-5 [48] (Gaudron and Gummow JJ).

133 Aronson, Groves and Weeks (n 22) 823-4.

134 ADJR Act 1977 (Cth) s 5(1). There are similar formulations in state and territory judicial review legislation: Administrative Decisions (Judicial Review) Act 1989 (ACT) s 4A(2); Judicial Review Act 1991 (Qld) s 7(1)(a); Judicial Review Act 2000 (Tas) s 7; Administrative Law Act 1978 (Vic) s 11.

135 Aronson, Groves and Weeks (n 22) 829.

136 (1998) 194 CLR 247, 262-3 [38].

137 ADJR Act 1977 (Cth) s 11(3).

138 A 28-day period is set by the Administrative Decisions (Judicial Review) Act 1989 (ACT) s 10, Judicial Review Act 1991 (Qld) s 26 and the Judicial Review Act 2000 (Tas) s 23. In Victoria, the Supreme Court (General Civil Procedure) Rules 2015 (Vic) r 56.02 states that proceedings must be commenced within 60 days after the date when the grounds for the grant of the relief or remedy first arose.

139 Uniform Civil Procedure Rules 2005 (NSW) r 59.10.

140 Judicial Review Act 1991 (Q1d) s 46. 
extendable six-month limit for certiorari in Western Australia ${ }^{141}$ and the High Court. ${ }^{142}$ Nevertheless, delay is a relevant criterion for discretionary refusal of the prerogative orders and injunctive relief. ${ }^{143}$

\section{E Remedies}

A range of remedies are available in judicial review proceedings. At common law, certiorari allows a court to quash a decision; prohibition prevents decisions that are beyond jurisdiction; and mandamus requires the performance of public duties. In addition to these 'prerogative' writs, the courts are willing to issue the private law remedies of declaration and injunction in public law cases.

Some of these remedies find expression in section 75(v) of the Constitution, which gives original jurisdiction to the High Court where a 'writ of Mandamus or prohibition or an injunction is sought against an officer of the Commonwealth'. They are also broadly reflected in judicial review legislation. Under the ADJR Act, for example, the court may quash a decision with effect from a date of its choosing; ${ }^{144}$ refer a matter back to the decision-maker with such directions as it sees fit; $;{ }^{145}$ make an order declaring the rights of the parties; ${ }^{146}$ order a party to do or refrain from doing specified things where the court considers such an order is necessary to do justice between the parties; ${ }^{147}$ or direct the making of a decision. ${ }^{148}$

Importantly, the remedies available in judicial review are directed at remedying particular unlawful decisions. Even where a challenge is successful, it is often open to the decision-maker to reach the same outcome while avoiding the mistakes identified by the court. Judicial review is not geared towards addressing systemic issues in the state administration. ${ }^{149}$ This is a point of contrast to charity law, to which we now turn.

\section{THE PROMISE OF CHARITY LAW}

While typically privately created, charities pursue purposes that benefit the public, or as Turner describes it, 'privately created' obligations that are 'publicly prosecuted' ${ }^{150}$ Charities inherently involve a mix of the private and public spheres. In a broad sense, this mix involves autonomous decision-making about the creation

141 Rules of the Supreme Court 1971 (WA) ord $56 \mathrm{r} 1$.

142 High Court Rules 2004 (Cth) r 25.06.

143 Aronson, Groves and Weeks (n 22) 1018-23; Enid Campbell and Matthew Groves, 'Time Limitations on Applications for Judicial Review' (2004) 32(1) Federal Law Review 29, 33.

144 ADJR Act 1977 (Cth) s 16(1)(a).

145 Ibid s 16(1)(b).

146 Ibid ss 16(1)(c), (2)(a), (3)(b).

147 Ibid.

148 Ibid s 16(3)(a).

149 Aronson, Groves and Weeks (n 22) 5.

150 Christian Turner, 'Origins of the Public/Private Theory of Legal Systems' in Kit Barker and Darryn Jensen (eds), Private Law: Key Encounters with Public Law (Cambridge University Press, 2013) 117, 138. 
and pursuit of a charity's purposes by private persons rather than government, ${ }^{151}$ but with greater public accountability than is ordinarily the case for other private organisations. ${ }^{152}$ While boards or members of incorporated private entities or beneficiaries of private trusts may have rights to obtain review or pursue breaches in the making of controller decisions, persons who are merely recipients of services and nothing more would not. More extensive rights exist in relation to charities and the question is whether such greater public accountability can make up for any lacunae in administrative law safeguards against abuses of power.

Despite some analysis in England and Wales and Canada, charity law principles remain relatively underexplored in this area. ${ }^{153}$ Below, however, we identify charity law mechanisms that permit decisions to be challenged. The mechanisms are grouped into those relevant to a breach of duty in the making of a specific decision (Part IV(A)) and those relevant to systemic service delivery concerns (Part IV(B)). For each grouping of mechanisms, the scope, grounds, standing, time limits and remedies are compared with those discussed for judicial review in Part III. In working through these mechanisms, it is important to acknowledge that there is no significant body of authorities or well-established principles that guide their application. Indeed, material research is required simply to articulate the basic mechanisms. The lean body of Australian charity law has thus necessitated recourse to the case law of other jurisdictions to the extent they employ similar statutory provisions or common law concepts.

This suggests some material difficulties in pursuing charity law rights, as reflected in the 'lean body' of charity law decisions. However, the trend to outsourcing indicates that pressure for accountability will build and this article is a step toward clearer charity law mechanisms for that accountability. While test case funding has enabled a series of authoritative charity taxation decisions, ${ }^{154}$ at the request of the $\mathrm{ACNC}$, the federal government provided additional funding in

151 Harding describes this as 'voluntarism': individual pursuit of the common good by persons making autonomous choices, rather than collective pursuit of the common good by the state: Matthew Harding, 'Distinguishing Government from Charity in Australian Law' (2009) 31(4) Sydney Law Review 559, 572. Cf Central Bayside General Practice Association Ltd v Commissioner of State Revenue (2006) 228 CLR 168, 181, 185-7 (Gleeson CJ, Heydon and Crennan JJ) applying a control test in the case at hand but leaving open the question of whether governmental control would always preclude charity status, 211 (Kirby J) noting that some bodies forming a part of government might potentially be charitable. For charities registered under the Charities Act 2013 (Cth), see the exclusion of 'government entities': ss 4, $5(d)$.

152 For assertions of public accountability principles infusing other private organisations, see, eg, Michael J Whincop and Mary E Keyes, 'Corporation, Contract, Community: An Analysis of Governance in the Privatisation of Public Enterprise and the Publicisation of Private Corporate Law' (1997) 25(1) Federal Law Review 51. For discussion of a range of ways in which the public/private spheres can be conceived for charities, cf Kathryn Chan, 'Not-for-Profit Organizations, Public Law and Private Law' in Matthew Harding (ed), Research Handbook on Not-for-Profit Law (Edward Elgar, 2018) 211.

153 As to charity trustees (not incorporated charities), see Jonathan Garton, 'The Judicial Review of the Decisions of Charity Trustees' (2006) 20(3) Trust Law International 160. As to standing, see Chan, The Public-Private Nature of Charity Law (n 31) 81-97, 121-5.

154 See, eg, Commissioner of Taxation v Word Investments Ltd (2008) 236 CLR 204; Aid/Watch Inc (2010) 241 CLR 539. 
2018-19 for litigation which is partly intended to help clarify charity law. ${ }^{155}$ The Israel Folau dispute also demonstrates the potential for social media fundraising where a case sparks public interest or sympathy. ${ }^{156}$

\section{A Mechanisms Based on Breach of Decision-Maker Duties}

Due to their position as property holders and/or decision-makers, charity controllers, be they trustees, company directors or committee members, are subject to a range of common law and statutory duties of care, skill and diligence and of loyalty and good faith. ${ }^{157}$ As discussed below, persons with delegated decisionmaking authority may also owe a range of such duties. Charity law provides three key mechanisms for persons who receive or who are potentially eligible to receive services from a charity, but who are not members or beneficiaries, to obtain a remedy in relation to breach of these duties. Each of the three mechanisms is sketched below, followed by comparison of the scope, grounds, standing, time limits and remedies with judicial review.

\section{Charity Proceedings Legislation}

Successor legislation to the repealed Charities Procedure Act 1812, 52 Geo 3, c 101 has been enacted in most Australian jurisdictions to provide a simpler procedure for bringing actions to enforce or relating to the administration of charitable trusts. ${ }^{158}$ Amongst other things, the legislation permits the relevant Attorney-General and certain other persons to apply for orders on the grounds of breach of duty in the administration of charities. ${ }^{159}$ As discussed in Part IV(A)(6), those other persons potentially include dissatisfied service recipients.

In Western Australia, the Attorney-General, a public service officer or 'any other person' may apply for an order requiring the trustees to 'carry out the trusts' or to meet their liabilities for any breach of trust. ${ }^{160}$ The Court determines which persons are to be heard. ${ }^{161}$ In Queensland, the Attorney-General or a person authorised by them and 'any person interested in the due administration of the

155 Australian Charities and Not-for-Profits Commission, 'ACNC Receives Additional Funding in 2018-19 Federal Budget' (News Release, 10 May 2018).

156 Lisa Martin, 'Israel Folau Donations Soar Past \$2M: As Australian Christian Lobby Cashes in', The Guardian (online, 27 June 2019) <https://www.theguardian.com/sport/2019/jun/27/israel-folaudonations-soar-past-2m-as-australian-christian-lobby-cashes-in $>$.

157 For a general discussion of such duties, see, eg, GE Dal Pont, Law of Charity (LexisNexis Butterworths, $2^{\text {nd }}$ ed, 2017) ch 17; Treasury (Cth) (n 32) 57-8.

158 Victoria repealed its charity procedures legislation on the basis that the Supreme Court already had common law jurisdiction to deal with allegations of breach of trust: Explanatory Memorandum, Charities (Amendment) Bill 2006 (Vic) 5; Legal and Constitutional Committee, Parliament of Victoria, Report on the Law Relating to Charitable Trusts (Report No 34, May 1989) 116-18. No successor legislation applies in the Northern Territory.

159 See generally Dal Pont, Law of Charity (n 157) [14.37]-[14.53]. Section 1324 of the Corporations Act 2001 (Cth) ('Corporations Act') might also provide an avenue for dissatisfied service recipients of companies limited by guarantee, but as many of the Corporations Act duties do not apply for charities registered with the ACNC, s 1324 is unlikely to be a significant avenue.

160 Charitable Trusts Act 1962 (WA) ss 21(1)(a), (b).

161 Ibid s 21(3). 
trust' may apply on similar grounds. ${ }^{162}$ The court may make orders requiring the trustees to act as above or otherwise as it thinks fit ${ }^{163}$ or as may be just. ${ }^{164}$

In Tasmania, an action to restrain or remedy an abuse, a misapplication or an illegal administration of charitable trust property must be brought by the AttorneyGeneral or relator, or a person 'interested in the administration of the trust' ${ }^{165}$ The Attorney-General's right to enforce the execution of a charitable trust is reiterated. ${ }^{166}$ A broader provision also exists, permitting persons 'directly interested in the charitable trust' to apply for 'any relief the case requires' where there has been a breach or alleged breach of charitable trust. ${ }^{167}$

In South Australia and the Australian Capital Territory, in addition to the Attorney-General, several further classes of listed persons may apply for relief if there is a breach or suspected breach of trust and the court may make any order it considers just. ${ }^{168}$ Prescribed persons include a person who has previously received money or other property from the charitable trust for its purposes, a person who is a member of a class that the charitable trust is intended to benefit, or any other person who satisfies the court that they have a 'proper interest' (South Australia) or 'relevant interest' (Australian Capital Territory) in the trust. ${ }^{169}$

In New South Wales, proceedings for breach of trust require a person to obtain the authorisation of the Attorney-General or leave of the court. ${ }^{170}$ The AttorneyGeneral has standing and the Attorney-General can authorise a person who does not otherwise have standing to bring proceedings. ${ }^{171}$ While imposing an additional barrier, the New South Wales legislation provides only limited additional support as it defines charitable trust proceedings in a way that suggests the court must already have jurisdiction. ${ }^{172}$ Further, the extended range of orders provided to the court are only available if there has been 'misconduct or mismanagement in the administration' of the trust and the court considers it 'necessary or desirable to act for the purpose of protecting existing or future trust property or securing a proper application, for the purpose of the charitable trust, of existing or future trust property' ${ }^{173}$ The additional orders that the court may make, which relate to matters such as removing and replacing trustees and protecting property, ${ }^{174}$ also do not appear very relevant to a breach of trust for a decision about whether to provide or stop providing a service to a person, unless that breach is evidence of systemic behaviour.

\footnotetext{
162 Trusts Act 1973 (Qld) ss 106(1), (2).

163 Charitable Trusts Act 1962 (WA) s 21(1).

164 Trusts Act 1973 (Qld) ss 106(1), (4).

165 Supreme Court Civil Procedure Act 1932 (Tas) s 57(2).

166 Ibid s 63.

167 Supreme Court Rules 2000 (Tas) r 767.

168 Trustee Act 1925 (ACT) ss 94A(1), 94B; Trustee Act 1936 (SA) ss 60(1), 67.

169 Trustee Act 1925 (ACT) s 94A(2); Trustee Act 1936 (SA) s 60(2).

170 Charitable Trusts Act 1993 (NSW) ss 5, 6.

171 Ibid ss 6(3), (4). The provisions assume standing at common law for persons with a special interest in the charity: Metropolitan Petar v Mitreski [2001] NSWSC 976, [3]-[9] (Hamilton J) ('Mitreski').

172 Charitable Trusts Act 1993 (NSW) s 5.

173 Ibid s 7.

174 Ibid.
} 
The provisions generally refer to charitable trusts or schemes. It is thus unclear whether the legislation applies in all cases to incorporated charities. The authorities are inconsistent about whether property held for the general purposes of an incorporated charity is to be treated as being held on charitable trust. Some cases refer to incorporated charities holding their property subject to trustee or 'analogous' obligations; $;{ }^{175}$ while some in an insolvency context have proceeded on the basis that there is no trust. ${ }^{176}$ Still others have found it unnecessary to decide that a trust exists, being able to enliven the relevant jurisdiction in the case of an incorporated charity on the basis of the obligation under its constitution to apply its assets to charitable purposes. ${ }^{177}$ The authors consider that the concept of a charitable trust, scheme or gift, as used in the charity proceedings legislation, can be construed sufficiently broadly to encompass obligations to pursue charitable purposes imposed under an entity's constitution or other governing rules (analogously to Liverpool and District Hospital for Diseases of the Heart $v$ Attorney-General) ${ }^{178}$ or because it reflects the court's inherent jurisdiction (discussed below).

\section{Inherent Jurisdiction}

The charity proceedings legislation was not intended to replace the existing common law jurisdiction of the court to supervise charitable trusts and to hear applications for relief in respect of breaches of trust. ${ }^{179}$ Accordingly, if the charity proceedings legislation does not apply, for instance, as in the case of Victoria and, potentially, the Northern Territory and generally in relation to incorporated charities, then the inherent jurisdiction will be highly relevant. In relation to incorporated charities, whether based on trustee or analogous obligations or an obligation arising from the corporation's constituent documents, incorporated charities are subject to the court's inherent supervisory jurisdiction ${ }^{180}$ and the

175 See, eg, Sydney Homoeopathic Hospital v Turner (1959) 102 CLR 188, 221 (Kitto J); Sir Moses Montefiore Jewish Home v Howell \& Co (No 7) Pty Ltd [1984] 2 NSWLR 406, 416 (Kearney J); Australian Executor Trustees Ltd v Ceduna District Health Services Inc [2006] SASC 286, [23] (Vanstone J); Liverpool and District Hospital for Diseases of the Heart v A-G [1981] Ch 193, 209-11, 214-15 (Slade J) ('Liverpool'). See also Ian Dawson and John Alder, 'The Nature of the Proprietary Interest of a Charitable Company or a Community Interest Company in Its Property' (2007) 21(1) Trust Law International 3, 3.

176 See, eg, Re Australian Elizabethan Theatre Trust (1991) 30 FCR 491, 505-7, 510 (Gummow J); Re ARMS (Multiple Sclerosis Research) Ltd [1997] 1 WLR 877, 881 (Neuberger J); Re Wedgwood Museum Trust Ltd (In Administration) [2013] BCC 281.

177 This is an alternative construction of the leading case: Liverpool [1981] Ch 193. See, eg, G E Dal Pont, “"Charity” and Trusts: Mutuality or Intersection?' (2016) 10(1) Journal of Equity 26, 45-7.

178 In Queensland this is bolstered by the relevant provisions expressly providing standing to an incorporated charity to apply for an order in respect of the relevant 'trust': Trusts Act 1973 (Qld) s 106(2)(b).

179 A-G v Church of England Property Trust, Diocese of Sydney (1933) 34 SR (NSW) 36, 52 (Long Innes J) ('Church of England Property Trust'). As to the relationship between the charities procedure legislation and the common law, see generally above n 159; Mitreski [2001] NSWSC 976, [7]-[9] (Hamilton J). As to the common law jurisdiction, see, eg, Sherborne (1854) 18 Beav 256; 52 ER 101, 110-11 (Romilly MR).

180 Liverpool [1981] Ch 193, 214 (Slade J); Re Padbury (1908) 7 CLR 680, 695-6 (O'Connor J); Re Dominion Students Hall Trust [1947] Ch 183, 186-7 (Evershed J). See also Kostka v Ukrainian Council of NSW Inc [2013] NSWSC 222, [52]-[56] (Young AJ). 
relevant Attorney-General has standing to enforce the charity's purposes. ${ }^{181}$ The inherent jurisdiction will also be pertinent where the charity proceedings legislation applies, but only to some breaches, as in New South Wales, even if it is still necessary to obtain the consent of the Attorney-General or leave of the court. ${ }^{182}$

Relevant orders that the court may make include a declaration, for instance, that a charity decision is invalid, ${ }^{183}$ or an injunction to stop the implementation of a decision in breach of trust, such as attempting to eject the members of a congregation from church property. ${ }^{184}$

\section{Third Party Action by a Regulator or Attorney-General}

Regulators of for-profit entities are not typically focussed on the provision of services by those entities to recipients, other than in relation to specific activitybased standards ${ }^{185}$ or selected foci such as consumer protection, competition and avoiding discrimination. ${ }^{186}$ In contrast, charity law focuses on the pursuit of purposes that benefit the public and so charity regulators must also concentrate on the benefits or services provided. In particular, one of the purposes for which the $\mathrm{ACNC}$ is established is to maintain, protect and enhance public trust and confidence in the Australian not-for-profit sector. ${ }^{187}$ One way this is achieved is by the application of a national regulatory framework for charities, ${ }^{188}$ under which the ACNC monitors and manages compliance, typically considering the impact of any enforcement action on the welfare of charity recipients. ${ }^{189}$

Under the regulatory framework, charities registered with the ACNC are subject to ACNC governance standards. ${ }^{190}$ Pertinently, governance standard 5 requires a charity to ensure that its 'responsible entities' comply with a broad range of skill and diligence and good faith and loyalty duties. ${ }^{191}$ The term 'responsible

181 Gaudiya Mission v Brahmachary [1998] Ch 341, 350 (Mummery LJ, Morritt LJ agreeing at 355); $A-G v$ Coopers' Co (1812) 19 Ves Jun 187; 34 ER 488.

182 Charitable Trusts Act 1993 (NSW) ss 5, 6.

183 For instance, such declarations as to invalidity were considered but not made, while a declaration that rents were held on trust was made: Church of England Property Trust (1933) 34 SR (NSW) 36, 53-7 (invalidity), 57-9 (rents) (Long Innes J).

184 See, eg, Newsome v Flowers (1861) 30 Beav 461; 54 ER 968, 972 (Romilly MR) ('Newsome’). See also Rigall v Foster (1853) 18 Jur 39. Other orders might also be made, such as ordering the trustees to account or to make equitable compensation. However, these orders are likely to be irrelevant where the dispute is about ending or failing to provide services.

185 Such as the quality assurance requirements that apply to education providers, or the safety and quality requirements for health and aged care providers.

186 Contractual obligations under government contracts for the delivery of services can also be viewed as a form of regulation and such obligations can be extensive. See, eg, Contribution of the Not-for-Profit Sector (n 1) 115.

187 ACNC Act 2012 (Cth) ss 15-5, 15-10, 105-15, 110-5, 110-10.

188 Ibid s 15-5(2).

189 Australian Charities and Not-for-Profits Commission, 'Commissioner's Policy Statement: Compliance and Enforcement' (CPS 2013/01, 12 October 2017) 5; ACNC Act 2012 (Cth) ss 35-10(2), 80-5(3), 855(2), 100-10(9), 100-15(6).

190 There are some restrictions on these standards. For instance, they do not apply to basic religious charities: ACNC Act 2012 (Cth) s 45-10(5). Transitional rules also provide exemptions to registered charities in certain circumstances: Australian Charities and Not-for-Profits Commission Regulation 2013 (Cth) pt 2-2 div 45 sub-div 45-D ('ACNC Regulation').

191 ACNC Regulation 2013 (Cth) reg 45.25. 
entity' is defined to include company directors, management committee members and trustees, ${ }^{192}$ but not delegates such as a non-director CEO or other employees.

Prior to the ACNC, there had been concerns about the practical enforcement of charity controller duties by other regulators, such as the Australian Taxation Office or the Australian Securities and Investments Commission, or by state and territory Attorneys-General. ${ }^{193}$ In contrast, the ACNC's core focus is charities. It has a sliding scale of potential regulatory responses to breaches such as entering into enforceable undertakings, issuing directions, applying for injunctions and suspending or removing responsible entities, some of which can be instituted without the need for a court order. ${ }^{194}$ Registered charities are now subject to regular financial and non-financial reporting to the ACNC and the ACNC has significant additional information gathering and monitoring powers. ${ }^{195}$ There is thus room for the ACNC to assist existing and potential service recipients. Further, the ACNC's resourcing and information base permits fruitful cooperation with other regulators and Attorneys-General, who may now be more willing to act.

\section{The Scope of Charity Law}

The charity proceedings provisions, inherent jurisdiction and the ACNC governance standards all clearly apply to breaches of duty by decision-makers in the administration of a charity. Although the charity proceedings legislation in New South Wales applies only to a subset of breaches of duties, the full range of duties remain extant in the other jurisdictions or under the other mechanisms. It is thus critical to understand the range of duties, breach of which might ground a claim for relief or action by a regulator. While charities exist in a range of legal forms, with common forms identified in Part II, trustees, company directors or committee members and in some cases their delegates, are subject to a comparable range of common law and statutory duties of care, skill and diligence and of loyalty and good faith. ${ }^{196}$ There are variations in the content of those duties. Nevertheless, many of the core constraints are similar, and to the extent that company directors or incorporated association committee members are also subject to trustee or analogous duties as discussed in Part $\operatorname{IV}(\mathrm{A})(1)$, there may be increased equivalence.

A key question is, to which decision-makers and hence, which decisions, do the duties extend? The question bears some resemblance to the issue of scope for judicial review where only certain decisions are subject to review, such as those of an administrative character made under an enactment, or made by an officer of the Commonwealth.

192 ACNC Act 2012 (Cth) ss 205-30, 300-5 (director).

193 See, eg, Treasury (Cth) (n 32) 66; Senate Standing Committee on Economics, Parliament of Australia, Disclosure Regimes for Charities and Not-for-Profit Organisations (Report, 4 December 2008) 45, 49, 70.

194 ACNC Act 2012 (Cth) pt 4-2, ss 165-50, 170-25.

195 Ibid pt 4-1, pt 3-2 div 60.

196 While some of the Corporations Act 2001 (Cth) duties do not apply for companies limited by guarantee that are registered with the ACNC, the common law duties continue to apply: Corporations Act 2001 (Cth) pt 1.6. 
Depending upon the size and nature of the charity, the charity controllers may make individual service recipient decisions, or be more involved in setting and monitoring the policies about eligibility, quality and cessation of services. ${ }^{197}$ Breach by trustees, directors or committee members of the duties discussed above may then be more likely to occur in the creation and ongoing monitoring of the relevant policies. However, it may sometimes be the charity controllers who make the ultimate decision. Two of the four examples provided in the introduction involved the charity controllers making the relevant decision. ${ }^{198} \mathrm{~A}$ third related to a decision made by the CEO and to a second decision that appears to have been either made or ratified by the board. ${ }^{199}$ The fourth concerned a range of non-board decisions, along with the application of a housing provider's rental payment system policy. ${ }^{200}$ Further, it would typically be the trustees who determine the recipients of distributions under charitable trusts.

In any event, where powers are delegated by charity controllers to others who make service decisions pursuant to those powers, such as a committee or a CEO, then the position of the delegate(s) may, though not always, also result in some decision-making duties, such as fiduciary duties of loyalty and good faith and duties in relation to the exercise of powers. ${ }^{201}$ This might be due to fiduciary or statutory duties owed by senior executive officers, ${ }^{202}$ or the potential for an agency relationship to result in fiduciary duties.$^{203}$ Further, if delegates fail to act properly, in good faith, or to give genuine consideration in exercising their powers, in some circumstances charity controllers may be in breach of their duties of care, skill and diligence if they have failed to adequately supervise the delegates. ${ }^{204}$

From the description of the ACNC regime above, it is apparent that governance standard 5 relates only to breaches by charity controllers themselves, not delegates. In the case of breaches by delegates, the ACNC would need to establish a secondary breach of duty (eg, of care, skill and diligence) by the charity controllers before a charity would have contravened governance standard 5 .

197 See, eg, Sherborne (1854) 18 Beav 256; 52 ER 101; Scott v National Trust for Places of Historic Interest or Natural Beauty [1998] 2 All ER 705 ('Scott').

198 Gunning (1994) Times, 9 June 1994; Sherborne (1854) 18 Beav 256; 52 ER 101. For further factual examples, albeit in a different legal setting, see also $R v$ Servite Houses and Wandsworth London Borough Council (2001) 33 HLR 35; $R$ v Leonard Cheshire Foundation [2002] HLR 49.

199 Durney (2019) 57 VR 158.

200 Goode [2016] VCAT 93.

201 In addition to the subsequent bases, the provision of a power under a charity's rules to a person to determine the recipients of a service could also be thought of as analogous to the grant of a power of appointment, which is to be exercised on the settlor's behalf and not for the benefit of the holder of the power. Such a power is a fiduciary power. See, eg, Re Wills' Trusts Deeds [1964] Ch 219, 228-9 (Buckley J).

202 See, eg, Robert P Austin and Ian M Ramsay, Ford, Austin and Ramsay's Principles of Corporations Law (LexisNexis Butterworths, 2018) [8.045], [9.040]. See also below nn 205-8, 217-19.

203 See, eg, JD Heydon, MJ Leeming and PG Turner, Meagher, Gummow \& Lehane's Equity: Doctrines \& Remedies (LexisNexis Butterworths, $5^{\text {th }}$ ed, 2015) 176-85 [5-210]-[5-250]; John McGhee, Snell's Equity (Thomson Reuters, 33 $3^{\text {rd }}$ ed, 2015) [7-004], [10-007].

204 See, eg, Flynn v Mamarika (1996) 130 FLR 218, 225-6 (Martin CJ); Austin and Ramsay (n 202) [8.340.12]-[8.340.15]. Of course, defences to the breach may be available, including statutory protection for delegation as under Corporations Act 2001 (Cth) s 190. 
Clearly then, some decisions about the provision of an outsourced service to a recipient or potential recipient will be made by delegates and not all such delegates will be subject to the full range of duties discussed under Part IV(A)(4). Relying on a secondary breach by charity controllers is unlikely to capture all decisions. Accordingly, the scope of charity law review is likely to be highly dependent upon the circumstances of the particular decision-maker. Nevertheless, some broad comparisons can be made with judicial review. First, the decisions of many charity officers and employees are potentially within the scope of the charity law mechanisms, whereas judicial review is unlikely to apply very often in these circumstances. Second, it is only the decisions of some charity decision-makers that are within scope, as opposed to judicial review, which, where it applies, potentially covers even lower level decision-makers.

\section{Grounds of Review}

Duties that apply to the exercise of powers by fiduciaries, eg, in deciding whether to provide or to stop providing a service, require controllers and many delegates to exercise a power in good faith; ${ }^{205}$ in accordance with the purposes for which it was given and not for an ulterior purpose;206 to act upon 'genuine consideration' 207 and not act 'irrationally', 'irresponsibly', 'capriciously', or 'wantonly' ${ }^{208}$ Acting with genuine consideration when exercising powers means that charity controllers must take into account (material) relevant considerations and should not take into account (material) irrelevant considerations. ${ }^{209}$ Charity directors and trustees must also ascertain and follow the terms of their constitution or trust deed. ${ }^{210}$

These duties correspond substantially with administrative law reasoning process grounds and, to an extent, with the third category of administrative law grounds relating to matters such as acting without legal authorisation. ${ }^{211}$ As noted previously, reasoning process grounds include taking account of irrelevant considerations, acting for an improper purpose, or acting in bad faith. A distinction

205 For companies, see also Corporations Act 2001 (Cth) s 181(1)(a); Greenhalgh v Arderne Cinemas Ltd [1951] Ch 286, 291 (Evershed MR).

206 For companies, see also Corporations Act 2001 (Cth) s 181(1)(b); Howard Smith Ltd v Ampol Petroleum Ltd [1974] AC 821, 835 (Lord Wilberforce for the Court).

207 For companies, see also Rosemary Teele Langford, 'Solving the Fiduciary Puzzle: The Bona Fide and Proper Purposes Duties of Company Directors' (2013) 41(3) Australian Business Law Review 127, 1301, 134; Austin and Ramsay (n 202) [8.295].

208 Karger v Paul [1984] VR 161, 163-6 (McGarvie J); Lutheran Church of Australia (South Australia District) Inc v Farmers' Co-operative Executors and Trustees Ltd (1970) 121 CLR 628, 639 (Barwick CJ), 652-3 (Windeyer J) ('Lutheran'); $A-G$ (Cth) v Breckler (1999) 197 CLR 83, 99 [7] (Gleeson CJ, Gaudron, McHugh, Gummow, Hayne and Callinan JJ). See also John D Heydon and Mark J Leeming, Jacobs' Law of Trusts in Australia (LexisNexis Butterworths, $8^{\text {th }}$ ed, 2016) 326-7 [16-08]; Geraint Thomas, Thomas on Powers (Oxford University Press, $2^{\text {nd }}$ ed, 2012) ch 9 474-5.

209 Heydon and Leeming (n 208) [16-08]-[16-09]; Thomas (n 208) 520-2, 540. See also Scott [1998] 2 All ER 705, 718 (Robert Walker J); Lutheran (1970) 121 CLR 628, 639 (Barwick CJ).

210 Re Church of England Trusts Corporation (Wangaratta) [1924] VLR 201, 206-7 (Weigall AJ); Austin and Ramsay (n 202) [8.160]; Heydon, Leeming and Turner (n 203) 211-15 [5-385].

211 Cf William Gummow, 'Equity in the Modern Administrative State' in PG Turner (ed), Equity and Administration (Cambridge University Press, 2016) 295, 310-12. 
from the administrative law context does arise from the fact that often the power in an administrative law setting will arise under a statute that sets out the relevant matters for the decision-maker to consider. In relation to a charity decision, the scope of relevant considerations is likely to be less clear cut and will largely depend on the context. In particular, it is likely to rest on the terms of the relevant power, the wider context of the trust deed or constitution and the circumstances in which the charity was created. ${ }^{212}$ These may often be quite different from the circumstances and goals that would typically apply to a government service provider. Nevertheless, where specific criteria are set out in the charity's constituent documents in relation to a discretion, but the controllers exercise the discretion for reasons which have 'nothing to do with those criteria', this could amount to taking irrelevant considerations into account. ${ }^{213}$

Administrative law reasoning process grounds such as unreasonableness also overlap with duties that apply to the exercise of powers by fiduciaries. ${ }^{214}$ That is because such duties require that the decision-maker not act irrationally, irresponsibly, capriciously, or wantonly. The precise scope of this duty is hazy, but it seems to apply to an exercise of discretion that is so utterly unreasonable that no reasonable decision-maker could possibly have so acted. ${ }^{215}$ While there is conjecture over whether there is such an objective component to the good faith and best interests duties for directors, there is support for a test that requires a decision to not be one which no reasonable board of directors could think was in the interests of the company. ${ }^{216}$ Of course, this language reflects the Wednesbury standard and Part III(B) noted that Australian courts have moved to a broader standard of reasonableness review. Further, acting without legal authorisation as an administrative law ground can be compared with the duty to follow the terms of a charity's constitution or trust deed.

Duties of loyalty include duties not to permit a conflict of interest and duty, or of duty and duty; and not to obtain an unauthorised profit from a fiduciary position. ${ }^{217}$ Supplementary Corporations Act 2001 (Cth) duties also exist for companies limited by guarantee, such as avoiding improper use of position (section 182) or information (section 183) disclosing or participating in board meetings when having a material personal interest (sections 191, 194 and 195) and concerning related party dealings (chapter $2 \mathrm{E}$ ). ${ }^{218}$ A number of statutory provisions

212 Cf Thomas' discussion of the matters relevant to the duty to inquire and ascertain in relation to the exercise of a power: Thomas (n 208) 479.

213 Heydon and Leeming (n 208) [16-09].

214 ADJR Act 1977 (Cth) s 5(2)(g).

215 Harris v Lord Shuttleworth [1994] Pens LR 47, 53 [36]-[37] (Glidewell LJ, Evans LJ agreeing at 58 [81] and Waite LJ agreeing at 58 [82]); Elovalis v Elovalis [2008] WASCA 141, [50]-[51] (Martin CJ), [63] (Buss JA).

216 Westpac Banking Corporation v Bell Group Ltd (in liq) [No 3] (2012) 44 WAR 1, 169 [923] (Lee AJA), 541 [2796] (Carr AJA), cf 352-3 [1983]-[1988] (Drummond AJA).

217 Heydon, Leeming and Turner (n 203) 157-8 [5-065]; Queensland Mines Ltd v Hudson (1978) 18 ALR 1; Boardman v Phipps [1967] 2 AC 46; Cook v Deeks [1916] 1 AC 554.

218 Sections 182 and 183 apply also to officers and employees. 
augment the common law loyalty duties applying to incorporated association management committee members in some jurisdictions. ${ }^{219}$

The duties of loyalty, however, only partially cover the administrative law procedural grounds. Well-established principles of natural justice require that decision-makers should not be biased and that a person should be accorded a hearing prior to a decision that affects their rights or interests. There is no general right to reasons under the common law, but legislation such as section 28(1) of the Administrative Appeals Tribunal Act 1975 (Cth) and section 13 of the ADJR Act provide for a right to reasons in some circumstances. In addition, the Freedom of Information Act 1982 (Cth) allows for a request to be made to an agency that has outsourced the provision of a public service for access to documents held by the body that is contracted to perform the outsourced service. ${ }^{220}$

These procedural rules are clearly important in the delivery of public services. For instance, as noted in the introduction, if a school board decides to close a school or if a job service provider recommends that a job seeker receive a demerit, the issues of whether the community or job seeker are entitled to reasons and a hearing loom large.

While the duties of loyalty go some way to addressing bias or perceived bias on the part of a decision-maker, charity controllers are subject to only very limited natural justice obligations. ${ }^{221}$ For instance, there is typically no need to provide an opportunity to be heard to a potential benefit recipient before charity controllers exercise a discretion, provided charity controllers have informed themselves sufficiently so as to act upon genuine consideration. ${ }^{222}$ An exception is where charity controllers have fostered an expectation on the part of a benefit recipient that they will continue to receive a benefit, in which case there may sometimes be an obligation to provide a warning or perhaps a hearing. ${ }^{223}$ This may reflect a slight difference with administrative law procedural fairness grounds, where the courts have moved from 'legitimate expectations' to broader questions of fairness, although policies or representations made to the applicant may be relevant to this inquiry. Nevertheless, there has also traditionally been reluctance to force the disclosure of reasons for the exercise of discretions by trustees or directors, including charity controllers. ${ }^{224}$ This would make it more difficult to establish a

219 Most jurisdictions have such provisions. For examples, see, eg, Associations Incorporation Reform Act 2012 (Vic) s 83; Associations Incorporation Act 2015 (WA) ss 42-7. Some provisions apply to officers as well as committee members.

220 See s 6C.

221 More extensive natural justice obligations may apply in relation to dealings with members of a charity, but our focus is on the provision of services to non-members.

$222 \mathrm{Cf} R v$ Charity Commissioners for England and Wales; Ex parte Baldwin [2001] WTLR 137. More broadly, see, eg, Heydon and Leeming (n 208) [16-10].

223 Scott [1998] 2 All ER 705, 718 (Robert Walker J).

224 See, eg, Re Beloved Wilkes's Charity (1851) 3 Mac \& G 440; 42 ER 330, 333 (Truro LC); Hartigan Nominees Pty Ltd v Rydge (1992) 29 NSWLR 405, 433-8 (Mahoney JA), 442 (Sheller JA) ('Rydge'). While Schmidt v Rosewood Trust Ltd [2003] 2 AC 709 ('Schmidt') heralded a loosening of the approach to disclosure of trust documents, the principle from Re Beloved Wilkes's Charity has been confirmed to apply in England and Wales (post Schmidt) in Breakspear v Ackland [2009] Ch 32, although subject to the overriding discretion of the court: at 51-2 (Briggs J). In Australia, there remains reluctance to disclose material upon which decisions are based, albeit the approach is a little more permissive than Re Beloved 
breach. Predominantly the reluctance has been to maintain the autonomy of decision-makers, to protect confidentiality and privacy and to reduce the administrative burden of decision-makers. ${ }^{225}$ Such factors are less compelling in the context of charities that, by definition, have a purpose of achieving public benefit and that are subject to extensive regulation. Nor would confidentiality and privacy necessarily have as great a role for most charities, given that they are for purposes, not persons. There may therefore be some room for judicial relaxation of these strict standards, which would be broadly consistent with the more demanding degree of inquiry required in the context of superannuation funds in Finch $v$ Telstra Super Pty Ltd. ${ }^{226}$

This discussion suggests that there is minimal protection of procedural fairness rights under charity law. The patchiness of this protection is partially ameliorated by the fact that regulators like the ACNC, or the relevant Attorney-General, can take action and compel the provision of information. Some jurisdictions, namely Western Australia and Victoria, also specifically provide the Attorney-General with statutory rights to inquire into the administration of charitable trusts, ${ }^{227}$ or of charities generally, ${ }^{228}$ that appear broad enough to include the obtaining of reasons for decisions. ${ }^{229}$

\section{Standing}

It is patent that the Attorney-General may bring charity proceedings for breach of duties under the statutory provisions or under the court's inherent jurisdiction. The ACNC also has a mandate to take enforcement action under the ACNC Act. There is thus no bar to standing for charity proceedings brought by a regulator such as the ACNC or by an Attorney-General. For judicial review, the Attorney-General likewise has standing. The significant practical difference, though, is that the ACNC has a specific focus on charities and is funded to ensure that they are properly administered and so is more likely to make use of its standing.

Where charity proceedings are brought by a dissatisfied service recipient, the standing requirements are either equivalently restrictive to those for judicial review, or more open. As expounded below, under the charity proceedings legislation, Queensland and Tasmania accord standing to an interested person, being someone with an interest materially greater than or different to that of ordinary members of the public. Under the inherent jurisdiction, which is potentially relevant in Victoria, the Northern Territory and for incorporated charities, the person must have a 'special interest' in the charity. The administrative law and charity law interested person tests are not identical, but they

Wilkes' Charity: Rydge (1992) 29 NSWLR 405, 442-5 (Sheller JA). Further, evidential inferences might also practically compel disclosure by the charity controllers on some occasions: Scott [1998] 2 All ER 705, 718-19 (Robert Walker J).

225 See, eg, Karger v Paul [1984] VR 161, 165-6 (McGarvie J).

226 (2010) 242 CLR 254, 278 [56] (French CJ, Gummow, Heydon, Crennan and Bell JJ).

227 Charitable Trusts Act 1962 (WA) s 20.

228 Charities Act 1978 (Vic) ss 9(1), 10.

229 Queensland and South Australia also provide statutory mechanisms for investigating the administration of trusts generally: Public Trustee Act 1978 (Q1d) s 60 (assuming the Attorney-General is a person whose interests may be affected by the trust's operation); Trustee Act 1936 (SA) ss 84A-84F. 
are phrased in similar ways and focus on whether a person's interests have been sufficiently affected to justify an action, without permitting a flood of litigation. It is likely that many current service recipients and some potential service recipients would satisfy this requirement under any of the tests. An aggrieved person can seek the Attorney-General's fiat to pursue relator proceedings, without any need to meet the interested person tests, which is also the case for judicial review.

However, as set out below, charity law goes further. Under the charity proceedings legislation, South Australia and the Australian Capital Territory also expressly cover past or potential recipients of benefits. Additionally, Western Australia and New South Wales provide open standing.

\section{(a) Standing Equivalently Restrictive to Judicial Review: Interested Persons}

Three broad approaches are evident under the charity proceedings legislation: open standing, standing for current or potential 'beneficiaries'; and standing for 'interested' persons. Queensland and Tasmania fall into the latter category. The authorities emphasise that it is not possible to define the class of interested persons, although they suggest that to be 'interested', a person must have an interest that is 'materially greater than or different from that possessed by ordinary members of the public', ${ }^{230}$ such that they have 'some good reason for seeking to enforce the trusts of a charity or secure its due administration' ${ }^{231}$ A person who has benefitted or might benefit from pursuit of the charitable objects may well meet this test, ${ }^{232}$ although the cases emphasise that this will not always be so, because, for instance, the class of potential benefit recipients may be very large. ${ }^{233}$ Unlike the English charity proceedings legislation, the Queensland and Tasmanian provisions do not contain the 'protective filter' of court or regulator consent to an application for relief, which has been applied in some instances where the applicant appears to be pursuing a personal rather than public benefit from due administration of the charity. ${ }^{234}$ However, the provisions are based on terminology used in precursors to the English legislation and it may be that the potential for costs orders could act as

230 Re Hampton Fuel Allotment Charity [1989] Ch 484, 494 (Nicholls LJ). See also Dal Pont, Law of Charity (n 157) [14.48]-[14.50]; Royal Society for the Prevention of Cruelty to Animals $v$ A-G [2002] 1 WLR 448, 457-8 [21] (Lightman J).

231 Re Hampton Fuel Allotment Charity [1989] Ch 484, 494 (Nicholls LJ).

232 In relation to similarly worded provisions, see, eg, Scott [1998] 2 All ER 705 (members of deer hunting clubs and tenant farmers, in relation to a decision to ban deer hunting); Gunning (1994) Times, 9 June 1994, 9 (Arden J) (parents of children at a boarding school in relation to a decision to close the boarding school); Rosenzweig v NMC Recordings Ltd [2014] PTSR 261 (composer who had asked the charity to promote his musical compositions).

233 Re Hampton Fuel Allotment Charity [1989] Ch 484, 493 (Nicholls LJ). The broad interpretation of an interested person in the case was also influenced by the fact that a person generally required the consent of the Charity Commission or the court to bring proceedings. See also $A$ - $G$ v Bishop of Worcester (1851) 68 ER 530, 545 (Turner VC); Re Manchester New College (1853) 16 Beav 610; 51 ER 916, 919 (Romilly MR).

234 See, eg, Rosenzweig v NMC Recordings Ltd [2013] EWHC 3792, [28] (Norris J). Norris J was also influenced by a view that the claimed breaches of charitable trust were baseless and that litigation would consume all the charity's assets: at [31]-[35]. 
a filter. ${ }^{235}$ In any event, current service recipients and persons who have applied for services and been denied are likely to constitute a relatively confined pool.

Recall (Part IV(A)(2)) that charity proceedings legislation does not apply in Victoria and, potentially, in the Northern Territory and for incorporated charities. Moreover, the Tasmanian and New South Wales provisions concern only a subset of breaches of controller duties. Therefore, standing to bring an action under the court's inherent jurisdiction will frequently be relevant. However, the position at common law is not clear. ${ }^{236}$ It is uncontroversial that the Attorney-General is a necessary party to proceedings about a breach of charitable trust. ${ }^{237}$ Some authorities go further and maintain that the Attorney-General must bring an action for breach as plaintiff. ${ }^{238}$ However, 'persons with a special interest' in the charity have long been found to have standing to initiate those proceedings. ${ }^{239}$ Current or potential recipients of benefits from a charity have not always been found to have such an interest. ${ }^{240}$ Nevertheless, obiter dicta of the Privy Council suggest that the members of a New South Wales church congregation (ie, current and potential benefit recipients) can be persons with a special interest in respect of church property. ${ }^{241}$ This is consistent with obiter from an earlier House of Lords decision that, if not for a limitations statute, a group of poor persons who were the intended recipients of benefits under a charitable trust would have had a right to bring an action against the charity trustees. ${ }^{242}$ Potential recipients of educational benefits coming within a charitable trust preference clause for relatives of the charity founder, would likewise have had standing had they obtained consent of the then Charity Commission, as required by legislation. ${ }^{243}$

235 See, eg, Trustee Act 1936 (SA) s 68. As to the link to the English legislation and the relevance of the English case law, see, eg, Dal Pont, Law of Charity (n 157) [14.38]-[14.40].

236 In the English context, cf Chan, The Public-Private Nature of Charity Law (n 31) 89-92.

237 National Anti-Vivisection Society v Inland Revenue Commissioners [1948] AC 31, 62 (Lord Simonds). Num-Hoi, Pon-Yu, Soon-Duc Society Inc v Num Pon Soon Inc (2001) 4 VR 527, 533-5 (Harper J) ('Num Pon Soon Inc').

238 See, eg, Strickland v Weldon (1885) 28 Ch D 426, 430 (Pearson J); Ngarluma Aboriginal Corporation $R N T B C v A-G(W A)$ [2014] WASC 245, [53]-[54] (Allanson J - the cases relied upon do not support such a broad negation of standing). Cf Num Pon Soon Inc (2001) 4 VR 527, 533-5 (Harper J).

239 Mitreski [2001] NSWSC 976, [3]-[9] (Hamilton J); Lang v Purves (1862) 15 Moore PC 389; 15 ER 541, 553-4 (The Court). As to the history of actions for enforcement of charities and the range of persons able to apply for redress, see, eg, Gareth Jones, History of the Law of Charity: 1532-1827 (Cambridge University Press, 1969), especially at 16-21.

240 A-G v East India Company (1840) 11 Sim 380; 59 ER 920, 922-3 (Shadwell VC). Shadwell VC focussed predominantly on the standing of charity controllers and referred only obliquely to two additional plaintiffs (impoverished persons who were current recipients of alms from the charity) noting that none of the plaintiffs asked for relief that would be specific to them as opposed to also of relevance to the other alms people and charity controllers. The weight of the reasoning is therefore relatively low.

241 Lang v Purves (1862) 15 Moore PC 389; 15 ER 541, 553-4 (although the plaintiffs were found not to have an interest, the congregation of a church, as the potential objects of the charitable trust, would have had such an interest). See also Newsome (1861) 30 Beav 461; 54 ER 968, 972 (Romilly MR). Cf Eden Refuge Trust $v$ Hohepa [2011] 1 NZLR 197, 222 [104] (Duffy J).

242 President and Scholars of the College of St Mary Magdalen, Oxford v A-G (1857) 6 HL Cas 189; 10 ER 1267, 1275-6 (Lord Cranworth LC), 1277-8 (Lord Wensleydale).

243 Braund v Earl of Devon (1868) LR 3 Ch App 800, 806 (Page Wood LJ) 807-9 (Selwyn LJ) ('Braund'). Cf Davis v Jenkins (1814) 3 Ves \& B 151; 35 ER 436. 
The above cases suggest that the range of interested persons is likely to be relatively narrow and that it may cover some current or potential service recipients. While some authorities suggest that representatives of the whole group of potential service recipients may need to bring proceedings, where the breach pertains to a decision that impacts specifically on a particular service recipient, much of the rationale for any such requirement falls away. ${ }^{244}$ Further, a broader approach to standing has been adopted in New Zealand in Great Christchurch Buildings Trust $v$ Church Property Trustees. ${ }^{245}$ In that case, an incorporated charity with a purpose of preserving buildings damaged in the Canterbury earthquakes was found to have standing to seek relief under the court's inherent jurisdiction in respect of a decision of the Church Property Trustees about demolishing the Christ Church Cathedral. This was due partly to the public interest nature of the issue and of the Cathedral, the Building Trust's object of preserving historic buildings and the benefit of testing the alleged breach of trust in circumstances where the AttorneyGeneral might not seek review. ${ }^{246}$ As the examples discussed in the introduction demonstrate, matters of public interest and a lack of action by the state to protect the dissatisfied party's interests are not atypical in the context of recipients of outsourced services.

Accordingly, there is some scope for current and potential service recipients to use the court's inherent jurisdiction to challenge charity decisions. There are, however, disincentives. In particular, uncertainty about whether the AttorneyGeneral must initiate any action, uncertainty over the scope of interested persons and the risk that persons considered to have been unnecessarily joined as parties may not be able to recover their costs. ${ }^{247}$ One avenue that partially addresses the uncertainty over standing is for an aggrieved person to seek the Attorney-General's fiat to pursue relator proceedings as was discussed for judicial review. ${ }^{248}$ However, the Attorney-General's decision to grant or withhold their fiat is non-justiciable. ${ }^{249}$ Also, there are typically high procedural hurdles, such as providing counsel's opinion as to the merits of the matter, the 'appropriateness' of the proposed relators and whether the proposed relators need the fiat in order to have standing, ${ }^{250}$ which re-opens the uncertainty referred to above. Most jurisdictions also apply public interest considerations to determining the grant of a fiat. ${ }^{251}$ Further, the relator will be liable for their own costs and may be liable for costs ordered against the Attorney-General. ${ }^{252}$ Survey data obtained by Saunders and Rabbat indicates that

244 Cf Braund (1868) LR 3 Ch App 800; A-Gv East India Company (1840) 11 Sim 380; 59 ER 920.

245 [2013] NZLR 230.

246 Ibid 246-7 [71]-[80] (Chisholm J).

247 Cf Re Lyell [1941] VLR 207.

248 A-G v Vivian (1826) 1 Russ 226; 38 ER 88, 91-2 (Lord Gifford MR). Although if the relator has no connection with the charity then this may be viewed unfavourably by the court, including as to costs. See, eg, Mayor of Southmolton v A-G (1854) 5 HL Cas 1; 10 ER 796, 806-7 (Lord Cranworth LC).

249 See, eg, Bateman's Bay (1998) 194 CLR 247, 259 (Gaudron, Gummow and Kirby JJ).

250 Cheryl Saunders and Paul Rabbat, 'Relator Actions: Practice in Australia and New Zealand' (2002) 13(4) Public Law Review 292, 294.

251 Ibid.

252 A-G v Dublin Corporation (1827) 1 Bli NS 312; 4 ER 888, 903-4 (Lord Redesdale); Wentworth v A-G (NSW) (1984) 154 CLR 518, 526-8 (Gibbs CJ, Mason, Brennan, Deane and Dawson JJ); A-G v Logan [1891] 2 QB 100, 103 (Wills J), 106-7 (Vaughan Williams J). 
only a handful of fiats were sought on all matters at the state and territory level in the 10 years to $2002 . .^{253}$ In only one jurisdiction did the fiats relate to charity matters.

\section{(b) Standing Broader than Judicial Review}

The charity proceedings legislation in Western Australia and New South Wales provides open standing. Not only do the Western Australian provisions provide standing to 'any other person', but they also refer to any officer of the public service (with no obvious limits on which officers can apply) and the court has the power to determine which persons should be heard in relation to an application, so that there is a mechanism to protect the court's time and charity resources. ${ }^{254}$ Case law on a mirror provision in New Zealand suggests that the court will adopt a 'noncensorious' approach. ${ }^{255}$ While authorisation must be sought from the AttorneyGeneral in New South Wales (or leave obtained from the court), even a person who would not otherwise have standing can be authorised.

As can be seen from the charity proceedings legislation described in Part IV(A)(1), South Australia and the Australian Capital Territory permit past or potential benefit recipients to seek a remedy. This would capture many dissatisfied current or potential service recipients.

\section{$7 \quad$ Time Limits}

The time limits for charity proceedings are sometimes more generous than in judicial review. ${ }^{256}$ Under the $A D J R$ Act and state and territory statutory judicial review regimes, time limits may be as short as 28 days. Where time limits are more flexible, for example extendable multi-month periods under the High Court's original jurisdiction or at common law in the states and territories, delay in the making of an application is recognised as a ground on which prerogative remedies and injunctive relief may be denied.

In contrast, equitable constraints on charity law proceedings such as the defence of laches are likely to be far more generous ${ }^{257}$ and, in any event, would not apply to the broad range of statutory relief available (including through action of a regulator or Attorney-General) and discussed in Parts IV(A)(1), IV(A)(3) and IV(B). ${ }^{258}$ In some circumstances the limitations legislation may apply. In Western Australia and the Australian Capital Territory a six-year limit generally applies to any civil proceedings, ${ }^{259}$ which would capture a range of charity proceedings ${ }^{260}$

253 Saunders and Rabbat (n 250) 296.

254 Charitable Trusts Act 1962 (WA) ss 21(1), (3).

255 Morgan v Wellington City Corporation [1975] 1 NZLR 416, 421 (McCarthy P) (Court of Appeal).

256 In the UK context, cf Abacus Trust Co (Isle of Man) v Barr [2003] Ch 409, 420 [29] (Lightman J), cited in Pitt v Holt [2013] 2 AC 108, 123 [11] (Lord Walker).

257 As to the doctrine of laches, see, eg, GE Dal Pont, Law of Limitation (LexisNexis, 2016) ch 13.

258 Laches does not apply to statutory relief: Fisher v Brooker [2009] 4 All ER 789, 809 [79] (Lord Neuberger).

259 Limitation Act 1985 (ACT) s 11; Limitation Act 2005 (WA) s 13. See also Peter Handford, Limitation of Actions: The Laws of Australia (Thomson Reuters, $3^{\text {rd }}$ ed, 2012) [5.10.300].

260 In Western Australia, a six-year limit also generally applies to 'equitable actions' (Limitation Act 2005 (WA) s 27), which would apply to some charity proceedings, but not to the full range of statutory relief 
New South Wales and the Northern Territory provide, respectively, six and threeyear (or potentially longer in the case of fraud) limitation periods for actions for breach of trust. ${ }^{261}$ These could potentially apply to some charity proceedings, though not necessarily where there has been a breach of fiduciary duties by charity controllers of a non-trust charity. ${ }^{262}$ Nor would the ACNC be subject to such limitations in enforcing the $A C N C$ Act.

\section{$8 \quad$ Remedies}

The discretionary nature of remedies has been suggested as a point of distinction between judicial review and control of fiduciary discretions. ${ }^{263}$ While this may be true in other contexts, as noted in Part IV(A)(1), the court may typically make such orders (if any) as it considers just or fit under charity proceedings legislation, ${ }^{264}$ while equitable remedies under the court's inherent jurisdiction are discretionary. ${ }^{265}$ Seeking action by a regulator or by an Attorney-General also involves an element of discretion on the part of the regulator/Attorney-General as to whether they will act or grant a fiat for a relator action. Accordingly, discretion as to the relief provided is a factor for both judicial review and charity proceedings.

Charity law, though, provides a broader range of potential remedies than are available under administrative law. The charity proceedings legislation and inherent jurisdiction generally enable the court to make orders that correspond with those available for judicial review. For instance, the court may give directions in relation to the administration of the charity, ${ }^{266}$ declare that a charity decision is invalid, or issue mandatory or prohibitory injunctions to charity controllers about the making or implementation of a decision. ${ }^{267}$ The ACNC can also issue directions to charities and seek injunctions in relation to charity decisions. ${ }^{268}$

However, the remedies go further. In some circumstances, including as a result of multiple breaches of duty, ${ }^{269}$ the court may remove and/or replace the charity

discussed above. A three-year limit also applies, calculated from when time begins running on equitable principles for the commencement of the action. This is likely to result in a longer period than six years from the date of the cause of action: Dal Pont, Law of Limitation (n 257) [10.5].

261 Limitation Act 1969 (NSW) ss 47-8; Limitation Act 1981 (NT) ss 32-3. The limitations legislation in Queensland, Tasmania and Victoria arguably does not apply to charitable trusts because the breach of trust provisions are worded by reference to an action by a beneficiary: $A-G v$ Cocke [1988] Ch 414, 421 (Harman J); Dal Pont, Law of Limitation (n 257) [10.9]-[10.11].

262 See Dal Pont's discussion of Tito v Waddell [No 2] [1977] Ch 106: Dal Pont, Law of Limitation (n 257) [10.8]. A similar limitation period may be applied in equity in such circumstances by analogy to the statutory limitation period under limitations legislation or under other provisions such as section $1317 \mathrm{~K}$ of the Corporations Act 2001 (Cth) (six years), although not where it would be unconscionable to impose a bar. See, eg, Gerace v Auzhair Supplies Pty Ltd (in liq) (2014) 87 NSWLR 435, 456-8 (Meagher JA).

263 Abacus Trust Co (Isle of Man) v Barr [2003] Ch 409, 420 [29] (Lightman J), cited in Pitt v Holt [2013] 2 AC 108, 123 [11] (Lord Walker).

264 Although, as noted in above n 173, in New South Wales, the court must consider it necessary or desirable to act.

265 Cf Church of England Property Trust (1933) 34 SR (NSW) 36, 52-3 (Long Innes J), albeit that the court should not decline to exercise its jurisdiction except for good and sufficient cause.

266 Discussed in Part IV(B).

267 See above nn 160, 163-4, 167-8, 183-4.

268 See above $\mathrm{n} 194$.

269 Cf Re Mania Charity (1813) 1 Ves \& B 496; 35 ER 193. 
controllers, ${ }^{270}$ as may the ACNC. ${ }^{271}$ Another instance is the use of enforceable undertakings by the ACNC. For example, the ACNC has entered into an enforceable undertaking with the Yipirinya School Council Inc to improve governance for the benefit of the service recipients, being the Alice Springs community and the children served by the school..$^{272}$ The undertaking includes matters such as implementing internal financial controls and accountability mechanisms, procuring that all charity controllers attend governance training, establishing an advisory committee and implementing a complaints handling policy. The additional remedies may be particularly effective in dealing with systemic service delivery concerns, as discussed below.

\section{B Systemic Concern Mechanisms}

Where the charity decision that an individual complains of represents a systemic issue, the mechanisms discussed in Part IV(A) may well permit redress, given the breadth of the potential remedies and the whole of charity (in some cases, charity sector) focus of the courts, the relevant Attorneys-General and regulators such as the ACNC. However, additional mechanisms, especially administrative schemes or orders, permit a further degree of oversight. Those additional mechanisms are sketched below, followed by a discussion of the grounds and scope, standing, timing and remedies elements for both the additional mechanisms and, where applicable, the mechanisms already outlined in Part IV(A) - as they apply to systemic concerns.

\section{Administrative Schemes}

The court and, in some cases, the relevant Attorney-General, has the ability to settle administrative schemes, which alter the administrative machinery of a charity. ${ }^{273}$ The court's inherent jurisdiction is typically enlivened in order to resolve uncertainty in the mode of achieving charitable objects, ${ }^{274}$ although some descriptions of the jurisdiction are broader, with judges adopting language redolent of cy-près grounds ${ }^{275}$ such as where the current mode is 'inadequate or impractical'

270 In the context of charitable trusts, see, eg, Newsome (1861) 30 Beav 461; 54 ER 968, 972 (Romilly MR); Metropolitan Petar v Mitreski [2005] NSWSC 330, [8]-[14] (Hamilton J). Statutory provisions also exist. The underlying focus of the inherent jurisdiction and the statutory provisions is whether leaving the controllers in place will undermine the security of the trust property or the efficient and satisfactory administration of the charity and the faithful and sound exercise of powers in pursuit of the charitable objects: Dal Pont, Law of Charity (n 157) [17.23]. As to the applicability of these principles to incorporated charity controllers, see, eg, William Henderson, Jonathan Fowles and Julian Smith, Tudor on Charities (Thomson Reuters, $10^{\text {th }}$ ed, 2015) [19-077].

271 See above $\mathrm{n} 194$.

272 Australian Charities and Not-for-Profits Commission, 'ACNC and Yipirinya School Working Together to Improve Charity's Governance' (News Release, 3 February 2015).

273 As to the general circumstances in which administrative schemes are available, see, eg, Dal Pont, Law of Charity (n 157) [14.6]-[14.7], [14.10]-[14.13]. In limited circumstances, the courts' inherent jurisdiction is modified and enhanced by statute. See, eg, Charitable Trusts Act 1962 (WA) s 8.

274 Dal Pont, Law of Charity (n 157) [14.10], quoting Re Gott [1944] Ch 193, 197 (Uthwatt J).

275 Cy-près schemes are only likely to be relevant where service complaints are due to the achievement of the relevant charitable purpose becoming 'impossible' or 'impracticable', or in jurisdictions where legislation has broadened the grounds, where the trust purposes have 'ceased to provide a suitable and 
to achieve the charity's objects. ${ }^{276}$ Schemes can involve the appointment of charity controllers, the creation of rules regarding the management and control of charity property, regulation of the group of persons who can benefit and the restriction of charity controller discretions. ${ }^{277}$ Attorney-General v St John's Hospital, Bath [No 1] ('St John's Hospital, Bath'), ${ }^{278}$ potentially provides an example, as an administrative scheme was altered under the scheme jurisdiction so as to stop systemic under-charging for charity assets to the disadvantage of the poor persons intended to be assisted (out of the proceeds) through the charity's hospital and almshouses. In Merchant Bank \& Trust Co v Garrett ('Garrett'), ${ }^{279}$ an administrative scheme resulted in a charity trustee being directed to access endowed funds to pay an annual sum sufficient for the operation of a retirement home, comprising income and capital, if necessary. ${ }^{280}$ To pay only income and not capital as the trustee had intended, would otherwise have meant evicting all of the residents of the retirement home (which was the object of the perpetually endowed charitable trust).

\section{Administrative Orders under Charity Proceedings Legislation}

The charity proceedings legislation discussed in Part IV(A)(1) also enables the Attorney-General and the same further classes of persons to apply for orders, such as directions in relation to charity administration, not just on grounds of breach of duty, but on the broader basis that it would assist in the administration of the charity. The relevant wording refers, for instance, to proceedings being 'necessary for the administration or management or to the advantage or benefit of [a charitable] trust', ${ }^{281}$ 'upon application ... give directions in respect of the administration of the trust', ${ }^{282}$ proceedings deemed 'necessary or proper ... to provide for the administration of [a charitable] trust' ${ }^{283}$, proceedings 'with respect to the administration of a charitable trust' 284 and 'may apply ... for an order ...

effective method of using the trust property' or where 'inexpedient' to carry out the purpose. See, eg, Dal Pont, Law of Charity (n 157) [14.6], [15.2].

276 Corish v A-G (NSW) [2006] NSWSC 1219, [9] (Campbell J). See also Re University of London Charitable Trusts [1964] Ch 282, 284-5 (Wilberforce J); Re J W Laing Trust [1984] Ch 143, 153, 155 (Peter Gibson J); A-G v Dedham School (1857) 23 Beav 350; 53 ER 138, 140-1 (Romilly MR).

277 See generally Dal Pont, Law of Charity (n 157) [14.10].

278 (1865-6) LR 1 Ch App 92.

27933 So 2d 603 (Miss, 1948). The US doctrine of deviation is a form of administrative scheme jurisdiction in equity: Westlaw US, Bogert's The Law of Trusts and Trustees (online at June 2020) '20 The Administration of Charitable Trusts' § 396.

280 Ibid 604.

281 Trustee Act 1925 (ACT) s 94A(1); Trustee Act 1936 (SA) s 60(1). This extends the approach that giving advice (rather than directions) to trustees to help the trustees avoid committing breaches of trust would be for the advantage or benefit of the trust: Re Trusts of the Church of Saint Jude, Brighton [1956] SASR 46, 52 (Hannan AJ).

282 Trusts Act 1973 (Q1d) s 106(1).

283 Supreme Court Civil Procedure Act 1932 (Tas) s 63 (the wording is slightly narrower than that of the other jurisdictions).

284 Charitable Trusts Act 1993 (NSW) s 5(1). The limitations on the New South Wales legislation discussed in Part IV(A)(1) remain pertinent. 
giving directions in respect of the administration of the trust or any examination or inquiry'. 285

The precursor English legislation has been used as a ground for settling administrative schemes and the Australian equivalents could be put to the same use. ${ }^{286}$

\section{Grounds and Scope}

Judicial review is constrained by its focus on particular decisions as opposed to systemic issues, and its concern not to intrude upon the substance of administrative decisions. In contrast, the breach of duty mechanisms discussed in Part IV(A) enable the court or a regulator to concurrently consider breaches of duty in relation to multiple decisions, particularly where proceedings are brought by a regulator such as the ACNC or by an Attorney-General.

Further, the court's administrative scheme-making jurisdiction (Part IV(B)(1)) enables the court to alter the administrative machinery of a charity, for instance where the current mode is 'inadequate or impractical' to achieve the charity's objects. This might apply where there are systemic governance failures as in St John's Hospital, Bath, where a charity might be administered so as to obtain further resources for the charitable object, potentially raising the extent and standard of service delivery. This could also be the case where a controller decision would result in a very detrimental impact on service delivery as in Garrett. The charity proceedings legislation in many jurisdictions enables changes to be sought for the better administration of a charity in similar circumstances. Further examples of relevant circumstances that might ground the application of either mechanism are illustrated by the Yipirinya School Council Inc example in Part IV(A)(8). That is, matters such as a poor understanding and implementation of governance requirements or the lack of appropriate policies, such as a complaints handling policy. This role is clearly beyond the remit of judicial review and more akin to the jurisdiction of an Ombudsman to investigate issues of 'maladministration'.

\section{Standing}

To the extent that the Part IV(A) mechanisms or the Part IV(B)(2) charity proceedings administrative orders mechanism are used to address systemic issues, standing will broadly be equivalently restrictive or more open than that for judicial review. In the case of the administrative scheme jurisdiction, several AttorneysGeneral are given statutory standing to establish schemes in limited circumstances. ${ }^{287}$ Generally, however, it is the court's inherent jurisdiction that pertains and hence the common law position as to standing discussed in Part IV(A)(6) will apply such that standing for dissatisfied service recipients is similarly restrictive to that for judicial review.

285 Charitable Trusts Act 1962 (WA) s 21(1)

286 Re Shrewsbury Grammar School (1849) 1 Mac \& G 324; 41 ER 1290, 1293-4 (Cottenham LC).

287 Charitable Trusts Act 1993 (NSW) ss 12-14; Charitable Trusts Act 1962 (WA) s 8. The Western Australian provision expressly enables the charity trustees to initiate an application. 


\section{$5 \quad$ Time Limits}

Where the Part IV(A) mechanisms are relied upon to address systemic issues, time limits have already been discussed above. The position for the Part IV(B) mechanisms is similar, except that as they relate to prospectively improving or amending the administration of a charity and not necessarily to relief against charity controllers, the limitations legislation is likely to restrict such actions less frequently. ${ }^{288}$

\section{Remedies}

Injunctive relief and the replacement of charity controllers, already referred to in Part IV(A)(7), could clearly preclude systemic breaches of duty. For instance, injunctive relief was provided in Metropolitan Petar $v$ Mitreski in order to preclude a series of ongoing breaches of incorporated association committee members in failing to comply with Macedonian Orthodox Church rules and the directions of the Bishop. ${ }^{289}$ Altering rules and restricting discretions under the scheme jurisdiction or charity proceedings administrative orders would go further than addressing systemic breaches of existing rules and would permit the decisionmaking rules themselves to be changed so as to improve or extend service delivery.

Directions in respect of the administration of a charity could, in a manner akin to the ACNC's enforceable undertakings, address systemic governance concerns, such as by requiring charity controllers to undertake training or to implement relevant policies. This clearly lies well beyond the administrative law remedies of quashing a particular decision, requiring a decision-maker to remake a decision, or mandating or prohibiting certain actions in relation to a decision. Coercive remedies also exceed the relief that can be obtained from Ombudsmen.

\section{CONCLUSION}

The outsourcing of government services to charities under grant or contract potentially entails an erosion of public law mechanisms of accountability. Our concern is the limited availability of judicial review in such circumstances, and the potential of charity law to foster accountability of decision-makers to service recipients whose interests have been adversely affected. Charity law may enable litigants and courts to evade vexed threshold questions in administrative law about the private/public law divide and instead focus on substantive issues of maladministration. Grounds of review are available in charity law that are analogous to the reasoning process grounds and, to an extent, the third category of administrative law grounds for judicial review. Rules of standing in charity law are either equivalently restrictive to judicial review and in some cases more open. Further, time limits in charity law are often less onerous than in judicial review

288 For instance, because there is no relevant cause of action or because any cause of action continues to accrue. Cf Handford (n 259) [5.10.260], [5.10.450].

289 [2012] NSWSC 16, [188] (Brereton J). 
and charity law remedies are potentially more far-reaching given that they enable systemic issues of maladministration to be addressed.

To be sure, many of these charity law mechanisms are underdeveloped. There are also concerns about procedural fairness grounds, which are less available in the sphere of charity law than judicial review, yet may be significant for individuals who are aggrieved by service delivery failures. In addition, charity law does not so readily apply to decisions made by front-line charity employees. This may sometimes hamper the ability of charity law to hold decision-makers to account.

However, as identified at the outset, other private law avenues will frequently be unavailable. Further, while government agencies will typically hold extensive contractual and statutory powers over charity service providers, ${ }^{290}$ it is naïve to assume that government agencies or responsible ministers will routinely seek to challenge the service providers that they have selected. This is particularly so in areas such as employment services which have the potential to become politicised. In short, lawyers and scholars accustomed to public law mechanisms should not neglect the significant promise of charity law to hold charity decision-makers to account where they exercise discretionary powers in providing outsourced services. 